\title{
IUCN
}

\section{Recognising and reporting other effective area-based conservation measures}

World Commission on Protected Areas Task Force on OECMs
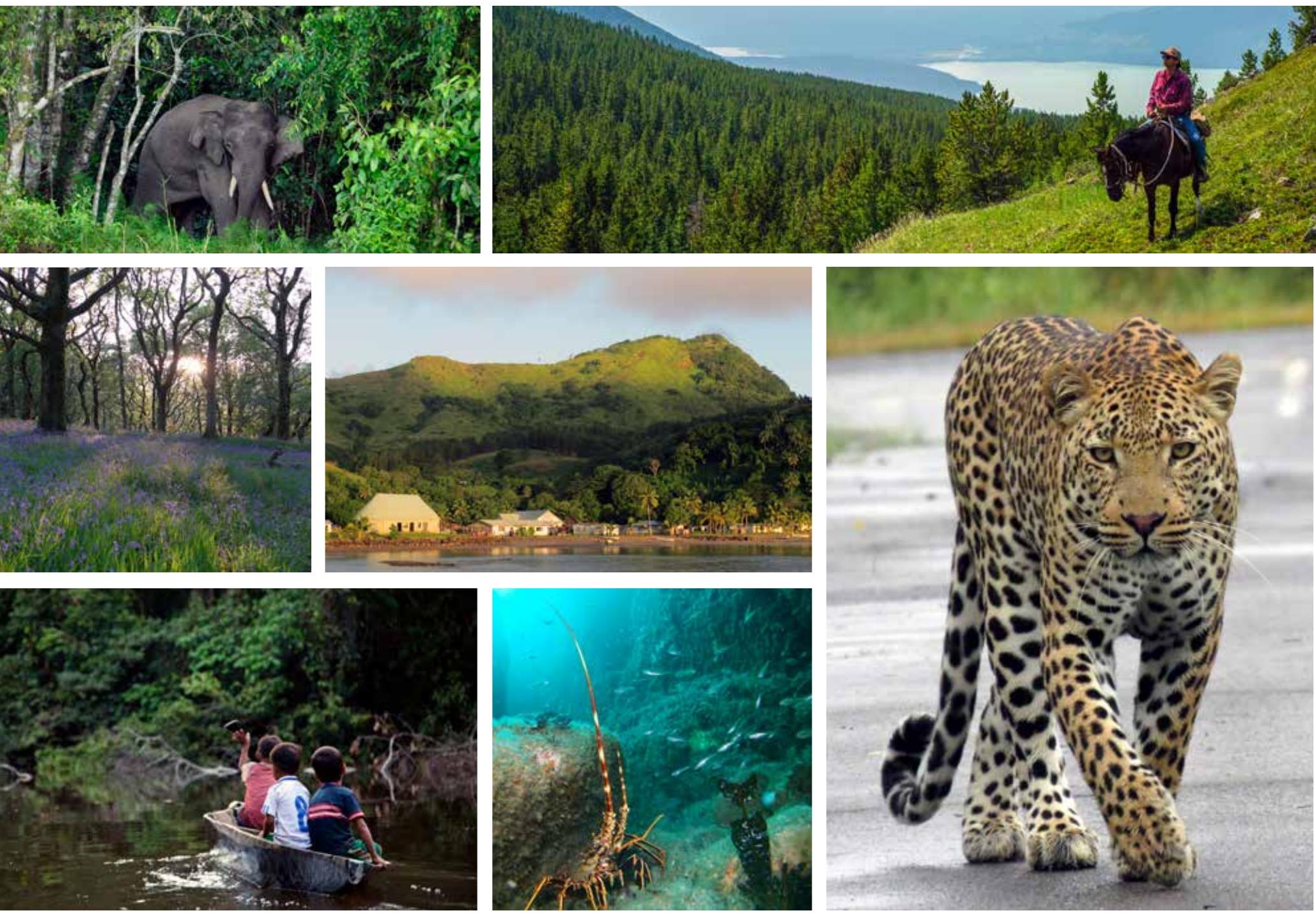

Protected Area Technical Report Series No 3

공 WCPA 谓 



\title{
Recognising and reporting other effective area-based conservation measures
}

\author{
World Commission on Protected Areas Task Force on OECMs
}


The designation of geographical entities in this book, and the presentation of the material, do not imply the expression of any opinion whatsoever on the part of IUCN or other participating organisations concerning the legal status of any country, territory or area, or of its authorities, or concerning the delimitation of its frontiers or boundaries.

The views expressed in this publication do not necessarily reflect those of IUCN or other participating organisations.

All examples are provided according to their condition and status as of the date of publication.

Published by: IUCN, Gland, Switzerland

Copyright: () 2019 IUCN, International Union for Conservation of Nature and Natural Resources.

Reproduction of this publication for educational or other non-commercial purposes is authorised without prior written permission from the copyright holder provided the source is fully acknowledged. Reproduction of this publication for resale or other commercial purposes is prohibited without prior written permission of the copyright holder.

Citation: IUCN-WCPA Task Force on OECMs, (2019). Recognising and reporting other effective area-based conservation measures. Gland, Switzerland: IUCN.

ISBN: 978-2-8317-2025-8 (PDF)

DOI: https://doi.org/10.2305/IUCN.CH.2019.PATRS.3.en

Cover photos: Top-left: 6. A pygmy elephant walks along the banks of the river within a community-governed area, near the village of Abai, within the Lower Kinabatangan-Segama Wetlands Ramsar Site, Sabah (Malaysia). (c) Harry Jonas. Top-right: William Myers from Yunesit'in, one of six Tsilhqot'in communities, on a horse pack trip into the mountains of Dasiqox Tribal Park (British Colombia, Canada). ( ) Jeremy Williams. Bottom-right: A leopard walks along the runway at the Hoedspruit Airforce Base as the base supports a conservation area of over 2000ha surrounding the base as a training and as a civilian buffer zone (Hoedspruit, South Africa). (C) Hoedspruit Airforce Base. Bottom-centre: An historic wreck site in the Isles of Scilly (United Kingdom) that excludes activities and provides an undisturbed environment for marine wildlife to flourish. Photo Credit: @ Dan Laffoley. Bottom-left: Local children discovering their surroundings in a conservation concession in Loreto Region, Peru. (C) Bruno Monteferri.

Left-centre: The Dyfi Biosphere Reserve in mid-Wales is made up of a mix of government and privately managed protected areas along with private lands, which are primarily farmed for sheep and cattle. The latter include areas with high biodiversity value, including ancient woodlands. As well as these values being recognised through the biosphere nomination and development, a multimillion pound initiative is focusing on restoring natural process in the Dyfi Valley, which encompasses mountains, pastures, woodlands, peat bogs and a large estuary and marine area with extensive sand dune complexes. Targeting at least 10,000 hectares of land and 28,400 ha of sea, the total area likely includes a range of potential OECMs. () Equilibrium Research.

Centre: Sun setting over Tovu village on Totoya Island (Fiji), where community leaders are integrating locally-managed marine area approaches with seascape scale planning. @ Stacy Jupiter

Back page: A young member of a Bajau family makes his way across a reef in the early-evening (Sabah, Malaysia). @ Harry Jonas.

\section{Design and layout: Miller Design}

Available from: International Union for Conservation of Nature (IUCN) Global Protected Areas Programme

Rue Mauverney 28

1196 Gland

Switzerland 


\section{Table of contents}

Foreword

Executive summary

Acknowledgements

Glossary of terms

Acronyms

List of boxes, tables and figures

1. Introduction

2. Definition and characteristics

3. Identifying other effective area-based conservation measures in practice

4. Monitoring and reporting other effective areas-based conservation measures

References

\section{Appendices}

Appendix I: The broad relationship between the Aichi Targets and Target 11

Appendix II: Decision support: Is Aichi Target 11 the most appropriate

Aichi Target against which to evaluate a conservation measure?

Appendix III: World Database on Protected Areas 


\section{Foreword}

Many areas outside national and regional protected area networks also contribute to the effective in-situ conservation of biodiversity. Appropriately recognising, reporting and supporting such areas is increasingly important in the context of biodiversity loss and climate change. Parties to the Convention on Biological Diversity (CBD) recognised early in the CBD's Strategic Plan (2011-2020) that 'other effective area-based conservation measures' (OECMs) offer a significant opportunity to achieve this aim.

Technical advice by the IUCN World Commission on Protected Areas Task Force on Other Effective Area-based Conservation Measures contributed towards the adoption by the CBD's $14^{\text {th }}$ Conference of the Parties of a definition, guiding principles, common characteristics and criteria for identification of OECMs (CBD Decision 14/8). The world now has an opportunity to better recognise de facto conservation that is taking place outside currently designated protected areas implemented by a diverse set of actors, including by indigenous peoples, local communities, the private sector and government agencies.

Appropriate recognition of OECMs provides the opportunity to engage and support rights-holders and stakeholders and to promote more equitable partnerships in global conservation efforts, highlighting the diversity of contributions to conservation globally. In doing so, OECMs will contribute to the conservation of biodiversity in many ways, such as: conserving important representative ecosystems, habitats and wildlife corridors; supporting the recovery of threatened species; maintaining ecosystem functions and securing ecosystem services; enhancing resilience against threats; and contributing to improved management and restoration of areas that could usefully support long-term in-situ conservation of biodiversity. OECMs can contribute to ecologically representative and well-connected systems of protected and conserved areas, integrated within wider landscapes and seascapes.

As with any 'new' framework, there will likely be a need for ongoing interpretation and implementation. Maintaining the full value of OECMs in promoting effective conservation is likely to require substantial efforts to build capacity at national and regional levels to identify, monitor and maintain their biodiversity values. OECMs provide an exciting opportunity to recognise and expand the conservation estate, under a range of governance and management regimes, as envisaged under Aichi Target 11. A key challenge will be how to recognise and support these fully conserved areas while also fulfilling national obligations for more sustainable management of production activities, including in areas of industrial forestry, agriculture and fishing that do not meet the OECM criteria but can also contribute to the Sustainable Development Goals (SDGs).

As Parties to the Convention deliberate the post-2020 Biodiversity Framework, these guidelines will continue to make an important contribution towards ensuring that OECMs are appropriately recognised and contribute to both coverage targets and ecological representation through 'systems of protected areas and other effective area-based conserved measures'.
Dr. Grethel Aguilar

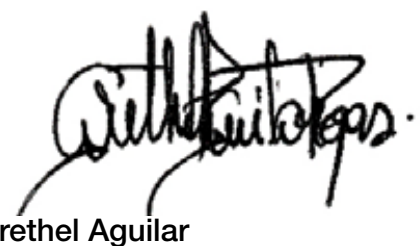

Acting Director General, International Union for Conservation of Nature

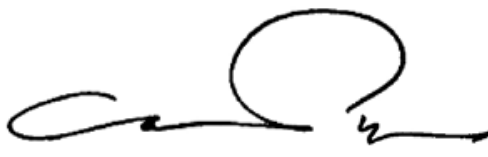

Dr. Cristiana Pașca Palmer

Executive Secretary,

Convention on Biological Diversity 


\section{Executive summary}

The Strategic Plan for Biodiversity 2011-2020, adopted in Nagoya, provides a framework for the effective implementation of the Convention on Biological Diversity (CBD) with 20 targets covering the period 2011-2020. Aichi Target 11 states that conservation will be achieved through effectively and equitably managed, ecologically representative and well connected systems of protected areas and other effective areabased conservation measures. While there were already clear definitions and criteria for protected areas this was not the case for 'other effective area-based conservation measures'.

In November 2018, this situation was remedied when Parties to the CBD adopted at the $14^{\text {th }}$ Conference of the Parties a definition of an "other effective area-based conservation measure" (OECM) as well as guiding principles, common characteristics and criteria for identification of OECMs (CBD/ COP/DEC/14/8). Decision 14/8 defines an OECM as:

\section{A geographically defined area other than a Protected Area, which is governed and managed in ways that achieve positive and sustained long-term outcomes for the in situ conservation of biodiversity with associated ecosystem functions and services and where applicable, cultural, spiritual, socio-economic, and other locally relevant values.}

While protected areas must have a primary conservation objective, this is not necessary for OECMs. OECMs may be managed for many different objectives but they must deliver effective conservation. They may be managed with conservation as a primary or secondary objective or long-term conservation may simply be the ancillary result of management activities.

Recognition of OECMs offers a significant opportunity to recognise de facto effective long-term conservation that is taking place outside currently designated protected areas under a range of governance and management regimes, implemented by a diverse set of actors, including by indigenous peoples and local communities, the private sector and government agencies. OECMs can contribute to ecologically representative and well-connected conservation systems, integrated within wider landscapes and seascapes, and in doing so, generate a range of positive conservation outcomes, such as:

- Conserving important ecosystems, habitats and wildlife corridors;

- Supporting the recovery of threatened species;

- Maintaining ecosystem functions and securing ecosystem services;

- Enhancing resilience against threats; and

- Retaining and connecting remnants of fragmented ecosystems within developed landscapes.

The WCPA Task Force on OECMs has produced these guidelines to assist Parties in interpreting and operationalising Decision 14/8 and to start to develop a body of good practice around recognising and reporting OECMs. It is designed for application at various scales, ranging from understanding whether an individual area is an OECM to reporting OECM statistics at the national and global level as a means to assess progress on achieving conservation targets.

Part 1 provides the background to the term 'other effective area-based conservation measures' and an overview of the process that led to CBD Decision 14/8.

Part 2 sets out the definition of an OECM and provides clear explanations of each element of the definition and criteria.

Part 3 sets out a simple screening tool that can be used to identify 'candidate OECMs' and provides an indicative list of examples of potential OECMs as well as of areas unlikely to meet the criteria. It is important that screening and the subsequent assessments are carried out on a site-by-site basis to ensure that areas meet the criteria for delivering effective conservation over the long term.

Part 4 elaborates the processes relevant to monitoring and reporting OECMs, with a focus on the global Protected Planet databases managed by the UNEP World Conservation Monitoring Centre. 


\section{Acknowledgements}

\begin{abstract}
These guidelines have been drafted by the IUCN-World Commission on Protected Areas' Task Force on Other Effective Area-based Conservation Measures. The Task Force worked for three years to support a process within the Convention on Biological Diversity (CBD) that resulted in CBD Decision 14/8 on "protected areas and other effective area-based conservation measures", adopted by 196 Parties at the 14th Conference of the Parties (November 2018). This technical advice relates directly to CBD Decision 14/8 on the recognition and reporting of other effective area-based conservation measures (OECMs), which are sometimes referred to as conserved areas.
\end{abstract}

\section{The Task Force was co-chaired by Kathy MacKinnon (WCPA Chair, UK) and Harry Jonas (UK/Malaysia) and consists of over 120 expert members. This draft was edited by the Co-Chairs and an editorial group comprising Nigel Dudley (UK), Marc Hockings (Australia), Dan Laffoley (UK), David MacKinnon (Canada), Trevor Sandwith (South Africa), and Stephen Woodley (Canada).}

\section{Four Task Force expert workshops were held: in} Cambridge, England (January 2016), Vilm, Germany (July 2016 and July 2019), Vancouver, Canada (February 2017). IUCN/WCPA wishes to thank the German Federal Agency for Nature Conservation (BfN), the Swiss Federal Department of the Environment, SwedBio, and the Canadian Parks and Wilderness Society (CPAWS) for their financial contributions to the work of the Task Force. We are grateful to staff at the UNEP World Conservation Monitoring Centre (UNEP-WCMC) in Cambridge (UK), Gisela Stolpe and Bettina Ohnesorge (BfN) in Vilm (Germany), and Sabine Jessen (CPAWS) in Vancouver (Canada) for their logistical support in organising and supporting these meetings. We also thank Sarat Gidda and colleagues at the CBD Secretariat for their active engagement throughout the process, including co-hosting a number of side events at meetings of the Parties.

During the development process, Task Force members and other experts provided much valuable feedback, information and case studies. We are grateful to the following people for their contributions (case study contributors are marked with an asterisk): Agnes Agama (Malaysia), Tundi Agardy (USA), Khaled Allam Harhash (Egypt), Helena Alvez-Pinto (Brazil), Thora Amend* (Germany), Michele Andrianarisata* (Madagascar), Ny Aina Andrianarivelo* (Madagascar), Ludi Apin (Malaysia), Alexandra Areiza (Colombia), Clarissa Arida (Philippines), Peter Auster (USA), Ghanimat Azhdari (Iran), Tim Badman (UK/Switzerland), Megan Barnes (Australia), Juan Bezaury-Creel (Mexico), Seema Bhatt (India), Dominique Bikaba (Democratic Republic of Congo), Heather Bingham* (UK), Grazia Borrini Feyerabend* (Italy/Switzerland), Peter Bridgewater (Australia), Johnny Briggs (UK), Thomas Brooks (UK/Switzerland), Jessica Brown* (USA), Jens Bruggemann* (Germany), Neil Burgess (UK), Catie Burlando (Italy), Stuart Butchart (UK), Pete Chaniotis
(UK), Maria Elfi Chávez (Colombia), Gladman Chibememe (Zimbabwe), Christie Chute* (Canada), Pepe Clark (Australia/ UK), Peter Cochrane (Australia), Laura Cornick (UK), Mark Costello (New Zealand), Mason Croft (USA), Adrian Davey (Australia), Mimi D'lorio (USA), Pablo Dominguez (Spain), Paul

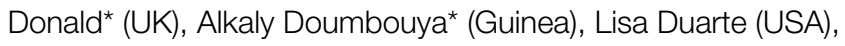
Steve Edwards (UK/Switzerland), Hany El Shaer (Egypt), Cristina Eghenter ${ }^{\star}$ (Italy), Shahul Faizi Hameed (India), Edgar Fernández (Costa Rica), Gregor Fischenich (Germany), Vin Fleming (UK), Amelia Fowles (Australia), Christine Franklin (USA), Sandra Galán (Colombia), Delfin Ganapin (Philippines), Carolina Garcia Imhof (Colombia), Sonali Ghosh (India), Rachel Golden Kroner (USA), Hugh Govan (UK/Fij), Stephen Grady (UK), Tarsicio Granizo (Ecuador), Tarsicio Granizo (Ecuador), Ania Grobicki (South Africa/Switzerland), Catalina Gutierrez (Colombia), James Hardcastle (UK/Switzerland), Terence HayEdie (Switzerland/Thailand), Yifan (Flora) He (China), Robert Hélie (Canada), Ro Hill (Australia), Amber Himes-Cornell (USA), Marc Hockings (Australia), Elaine Hsiao (Canada), Claudia Ituarte Lima (Mexico), Sabine Jessen* (Canada), Holly Jonas (Canada/Malaysia), Stacy Jupiter (USA/Fiji), Theodore Karfakis (Greece), Jennifer Kelleher (Republic of Ireland), Kate Kincaid (Canada), Jonathan Kirui (Kenya), Rebecca Klaus (UK), Naomi Kingston* (Ireland/UK), Eskild Kirkegaard (Denmark), Mirjam de Konig (Netherlands), Sigrid Kuehnemund (Canada), Barbara Lang (Germany/Benin), Thierry Lefebvre (France), Christopher Lemieux (Canada), Clare Lewis (UK), Harvey Locke (Canada), Julia Miranda Londono (Colombia), Ali Mahamane (Niger), Claudio Maretti (Brazil), Michael Mascia (USA), Lisa McLaughlin (Canada), Daniel Marnewick (South Africa), Clara Lucía Matallana-Tobón* (Colombia), Pradeep Mehta (India), Mehmet Metaj (Albania), Rossana Merizalde (USA), Amy Milam (USA), Carmen Miranda (Bolivia), Brent Mitchell* (USA), Rahul Mungikar (India) Daniel Mwamidi (Kenya), Helen Newing (UK), Onkemetse Nteta* (South Africa), Melissa Jane Nursey-Bray (Australia), Aboubacar Oularé (Guinea), Gisela Paredes (Colombia), Roberto Pereyra Lobos (Argentina), Jacques Perron* (Canada), Dimitra Petza (Greece/ltaly), Hugh Possingham (Australia), Jeff Pradel (Peru), Madhu Rao (India/ UK/Singapore), Andrew Rhodes* (Mexico), Ryan Richards (USA), Danielle Ryan (Australia), Marina Rosales (Peru), Carlos Saavedra (Colombia), Yoav Sagi (Israel), Marcela Santamaria (Colombia), Elsa Sattout (Lebanon), Klaus Schmitt* (Germany), Faizi Shahul Hameed (India), Sushma Shresthma (Nepal/ US) Joanna Smith (Canada), Dermot Smyth (Australia), Clara Solano (Colombia), Mark Spalding (UK), Candice Stevens (South Africa), Todd Stevenson (USA), Mavra Stithou (Greece), Sue Stolton (UK), Teki Surayya (India), Kim Taylor Thompson* (Canada), Parfait Tchuenfo (Cameroon), Anteneh Tesfaw (Ethiopia), David Thomas (UK), Ted Trzyna (USA), Agus Utomo* (Indonesia), Bas Verschuuren (Netherlands), Francis Vorhies (UK), Agus Budi Utomo* (Indonesia), John Waithaka* (Kenya), Sonam Wangchuk* (Bhutan), James Watson (Australia), Sue Wells (UK), Sheila Wertz-Kanounnikoff (Germany), Tara Whitty (USA), Hesti Widodo* (Indonesia), Ryan Wilkie (UK/Denmark), James Williams (UK), Linda Wong (China), Dale Wright (South 
Africa), Kim Sander Wright* (Canada), Llewellyn Young* (Hong Kong/Switzerland), Hag Young Heo (Republic of Korea), and Jinfeng Zhou (China).

Other individuals who kindly contributed inputs or case studies, include: Simon Albert (Australia), Eugenio Barrios (Mexico), Alexandra Barron (Canada), Nicole Bendsen (Germany), Bastian Bertzky (South Africa/Italy), Caroline Butler (Canada), Tony Charles (Canada), Sushila Chatterjee Nepali (Nepal), Roger Crofts (UK), Terence Dacles (Philippines), Steve Diggon (Canada), William Dunbar (USA/Japan), Kim Dunn (Canada), Jessica Elliott (Canada), Ninel Escobar (Mexico), Roman Eyholzer (Switzerland), Fred Ford (Australia), Robyn Forrest (Canada), Kim Friedman (Australia/Italy), Mervi Heinonen (Finland), Erich Hoyt (USA/UK), Olaf Jensen (Canada), Francois Lengrand (France), Satnam Manhas (Canada), Joe McCarter (New Zealand), Martine Maron (Canada), Chris McDougall (Canada), Günter Mühlbauer (Germany), Mariana Zareth Nava Lopez (Mexico), Saw Tun Khaing (Myanmar), Linda Nowlan (Canada), Shane Orchard (New Zealand), Allison Pritchard (Canada), Ravaka Ranaivoson (Madagascar), Sergio Salinas-Rodríguez (Mexico), Paul Scholte (Germany), Archana Sharma (USA), Rebecca Singleton (UK/Canada), Charlotta Sörqvist (Sweden), Bruce Stewart (Canada), Gary Tabor (USA), Kaori Tsujita (Japan), Siyu Qin (China/USA), Basile Van Havre (Canada), Liette Vasseur (Canada), Scott Wallace (Canada), Bill Wareham (Canada), Gladys Warigia Njoroge (Kenya), Mike Wong (Canada), Alison Woodley (Canada), Edgar Yerena (Venezuela), and Natori Yoji (Japan).

WCPA is also grateful to John Waithaka and Lucy Waruingi who organised a workshop in Kenya on draft Guidelines in 2017, and to the following individuals who field-tested the guidance in Bermuda: Alison Copeland, Peter Drew, Dan
Laffoley, Jeremy Madeiros, Sarah Manuel, Simieon Massey, Drew Pettit, Joanna Pitt, Philippe Rouja, Mandy Shailer, Robbie Smith, Tammy Trott, Craig Trott, and Julie Marshall. Production of a large number of case studies in Colombia was led by Clara Matallana (Instituto Humboldt), with support from Alexandra Areiza, Maria Elfi Cháves, Sandra Galán, Clara Solano, and Marcela Santamaria, and contributions from Jony Albeiro Arias, Luis Alimaco, Germán Andrade, Mónica Arroyave, Atanasio Barros, Hermes Carreño, Claudia Céspedes, Stephanie Gailer, Daniel Garavito, Pedro Garavito, Carolina Gil, Brian Hettler, Eduardo Londoño, Juanita Londoño, Jorge Hernán López, Ricardo Rey, Jerónimo Rodríguez Escobar, Alejo Sauna Mamatacán, Dignory Soto Londoño, José de los Santos Sauna, José Shibulata Zarabata, Carlos Vieira, and Jacinto Zarabata.

The process benefited from work done by the Canadian Council on Ecological Areas to develop guidance on other effective area-based conservation measures (MacKinnon et al., 2015) and is complemented by work on the relationship between Key Biodiversity Areas (KBAs), protected areas and other effective area-based conservation measures led by BirdLife International and partners (BirdLife, 2017). Workshops to test earlier versions of the guidance were held in Kenya, Colombia, Bermuda and South Africa. A Special Issue of the journal PARKS (IUCN-WCPA, 2018) provides some examples of case studies: see https://parksjournal.com/list-of-papers/

For more information on the Task Force, including all outputs and case studies, please see: www.iucn.org/theme/protectedareas/wcpa/what-we-do/oecms

Please refer any questions or feedback to:

oecm@wcpa.iucn.org 


\section{Glossary of terms}

Biodiversity: The variability among living organisms from all sources including, inter alia, terrestrial, marine and other aquatic ecosystems and the ecological complexes of which they are part: this includes diversity within species, between species and of ecosystems. (CBD Article 2).

Candidate OECM: A geographically defined space that has been identified as a "potential OECM" and the governance authority has consented to it being assessed against the CBD criteria.

Conserved areas: CBD Parties and other organisations are increasingly referring to "protected and conserved areas" (see for example CBD decision 14/8 and the IUCN Green List of Protected and Conserved Areas). In this context, "conserved areas" include areas that may satisfy the criteria for "other effective area-based conservation measures".

Cultural and spiritual values: These include recreational, religious, aesthetic, historic and social values related to tangible and intangible benefits that nature and natural features have for people of different cultures and societies, with a particular focus on those that contribute to conservation outcomes (e.g. traditional management practices on which key species, biodiversity or whole ecosystems have become reliant or the societal support for conservation of landscapes for the maintenance of their quality in artistic expression or beauty) and intangible heritage, including cultural and spiritual practices.

\section{Ecologically and Biologically Significant Marine Areas:} EBSAs are special areas in the ocean that serve important purposes, in one way or another, to support the healthy functioning of oceans and the many services that it provides. (https://www.cbd.int/ebsa/)

Ecosystem: A dynamic complex of plant, animal and microorganism communities and their non-living environment interacting as a functional unit. (CBD Article 2).

Ecosystem approach: The ecosystem approach is a strategy for the integrated management of land, water and living resources that promotes conservation and sustainable use in an equitable way. Application of the ecosystem approach will help to reach a balance of the three objectives of the Convention. It is based on the application of appropriate scientific methodologies focused on levels of biological organization which encompass the essential processes, functions and interactions among organisms and their environment. It recognizes that humans, with their cultural diversity, are an integral component of ecosystems. (https:// www.cbd.int/ecosystem/).

Free, prior and informed consent: Free, Prior and Informed Consent (FPIC) is a specific right that pertains to indigenous peoples and is recognised in the United Nations Declaration on the Rights of Indigenous Peoples. It allows them to give or withhold consent to a project that may affect them or their territories. Once they have given their consent, they can withdraw it at any stage. Furthermore, FPIC enables them to negotiate the conditions under which the project will be designed, implemented, monitored and evaluated. This is also embedded within the universal right to self-determination. (UN, 2007).

Geodiversity: The natural range (diversity) of geological (rocks, fossils, minerals), geomorphological (land form, physical processes) and soil features, and includes their assemblages, relationships, properties, relationships and systems. (Gray, 2004).

Governance authority: The institution, individual, indigenous peoples or communal group or other body acknowledged as having authority and responsibility for decision-making and management of an area.

Habitat: The place or type of site where an organism or population naturally occurs. (CBD Article 2).

Indigenous peoples and local communities: This report follows the Convention on Biological Diversity's uses of the terms "indigenous peoples" and "local communities".

In-situ conservation: The conservation of ecosystems and natural habitats and the maintenance and recovery of viable populations of species in their natural surroundings and, in the case of domesticated or cultivated species, in the surroundings where they have developed their distinctive properties. (CBD Article 2).

Locally managed marine area: A locally managed marine area $(L M M A)$ is an area of nearshore waters and its associated coastal and marine resources that is largely or wholly managed at a local level by the coastal communities, landowning groups, partner organizations, and/or collaborative government representatives who reside or are based in the immediate area. (http://Immanetwork.org/)

Management authority: The organisation or entity responsible for the ongoing management of a site. The management authority may or may not be the same as the governance authority, the organisation or entity that holds legal or customary authority and responsibility for the site.

Potential OECM: A geographically defined space that has been identified as having OECM-like characteristics by applying the screening tool but where the governance authority has yet to consent to it becoming a "candidate OECM".

Protected area: The CBD defines a protected area as: "A geographically defined area which is designated or regulated and managed to achieve specific conservation objectives" (CBD Article 2). IUCN has a more detailed definition: "A 
clearly defined geographical space, recognised, dedicated and managed, through legal or other effective means, to achieve the long-term conservation of nature with associated ecosystem services and cultural values" (Dudley, 2008). The CBD and IUCN recognise the two as being equivalent in practice (Lopoukhine and Dias, 2012) as in both cases these areas are intended to achieve in-situ conservation.

Sustainable use: The use of components of biological diversity in a way and at a rate that does not lead to the long-term decline of biological diversity, thereby maintaining its potential to meet the needs and aspirations of present and future generations. (CBD Article 2). 


\section{Acronyms}

$\begin{array}{ll}\text { CBD } & \text { Convention on Biological Diversity } \\ \text { COP } & \text { Conference of the Parties to the CBD } \\ \text { EBSA } & \text { Ecologically or Biologically Significant Marine Area } \\ \text { IBA } & \text { Important Bird Area } \\ \text { ICCA } & \text { Territories and Areas Conserved by Indigenous Peoples and Local Communities } \\ \text { IMMA } & \text { Important Marine Mammal Area } \\ \text { IPA } & \text { Important Plant Area } \\ \text { IUCN } & \text { International Union for Conservation of Nature and Natural Resources } \\ \text { KBA } & \text { Key Biodiversity Area } \\ \text { LMMA } & \text { Locally Managed Marine Area } \\ \text { OECM } & \text { Other Effective Area-based Conservation Measure } \\ \text { PAME } & \text { Protected areas management effectiveness } \\ \text { SBSTTA } & \text { Subsidiary Body on Scientific, Technical and Technological Advice of the CBD } \\ \text { SDGs } & \text { UN Sustainable Development Goals } \\ \text { UN } & \text { United Nations } \\ \text { UNEP } & \text { United Nations Environment Programme } \\ \text { UNEP-WCMC } & \text { UN Environment World Conservation Monitoring Centre } \\ \text { WCC } & \text { IUCN World Conservation Congress } \\ \text { WCPA } & \text { IUCN World Commission on Protected Areas } \\ \text { WDPA } & \text { World Database on Protected Areas }\end{array}$

\section{List of boxes, tables and figures}

Box 1: Identifying or establishing other effective area-based conservation measures 3

Box 2: $\quad$ A closer look at geographical space $\quad 5$

Box 3: Historic wreck sites e.g. Scapa Flow - an example of Ancillary Conservation 6

Box 4: $\quad$ A closer look at biodiversity $\quad 7$

Box 5: Using the screening tool-key points to address 8

Box 6: $\quad$ Ensuring that Aichi Target 11 is the right focus 10

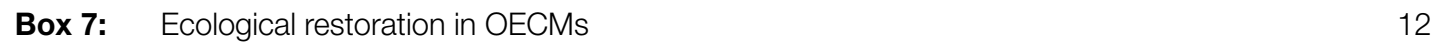

Table 1: Basic principles for verification of data for inclusion in the Protected Planet databases 13

Figure 1: The relationship between OECMs and protected areas 4 


\section{Introduction}

\section{Background}

The Strategic Plan for Biodiversity 2011-2020 is a framework for the effective implementation of the Convention on Biological Diversity (CBD) through a strategic approach, comprising a shared vision, a mission, and strategic goals and targets ("Aichi Biodiversity Targets"), which have inspired broad-based action by all Parties and stakeholders. Target 11, under Strategic Goal C, aims to improve the status of biodiversity by safeguarding ecosystems, species and genetic diversity. It states:

\section{By 2020, at least 17 per cent of terrestrial and inland water areas and 10 per cent of coastal and marine areas, especially areas of particular importance for biodiversity and ecosystem services, are conserved through effectively and equitably managed, ecologically representative and well connected systems of protected areas and other effective area-based conservation measures, and integrated into the wider landscapes and seascapes (emphasis added).}

Protected areas provide the foundation of national biodiversity conservation strategies and delivery of Target 11 (Watson et al., 2014). IUCN has provided guidance on the definition, management categories and governance types of protected areas (Dudley, 2008; Borrini-Feyerabend et al., 2013). Parties to the CBD included "other effective area-based conservation measures" (OECMs) in Target 11 because some areas outside the recognised protected area networks also result in the effective in-situ conservation of biodiversity. These can include territories and conserved areas governed by any of four governance types, i.e., by governments, private actors, indigenous peoples and local communities, and shared governance arrangements. Regardless of achievements under Target 11 by 2020, it is expected that both protected areas and OECMs will be part of any post-2020 targets to conserve biodiversity in situ and OECMs will become a more commonly used tool in conservation strategies.

Since 2010, Parties to the CBD have made substantial progress on expanding protected area systems, including declaration of many very large marine protected areas (UNEP-WCMC and IUCN 2016, 2018). There has been slower progress in defining, identifying, recognising and reporting OECMs (Jonas et al., 2014). The International Union for the Conservation of Nature (IUCN) and the IUCN World Commission on Protected Areas (WCPA) were invited by the Parties to the CBD to "develop technical guidance to achieve the full scope of Aichi Biodiversity Target 11" (CBD COP Decision XII/24). In 2015, WCPA established a Task Force to develop technical guidance on OECMs. Draft guidelines prepared by the Task Force were provided to the CBD Secretariat and shared with CBD Parties, discussed at two workshops convened by the CBD (February 2018) and presented in side events at meetings of the CBD's Subsidiary
Body on Scientific, Technical and Technological Advice (2016-2018). More information on the process of developing the Guidelines is available in a Special Issue of PARKS journal on OECMs (Jonas et al., 2018).

At the $14^{\text {th }}$ Conference of the Parties to the CBD (COP 14) in November 2018, Parties adopted a decision on "Protected areas and other effective area-based conservation measures" (CBD/COP/DEC/14/8, https://www.cbd. int/doc/decisions/cop-14/cop-14-dec-08-en.pdf). This decision adopted a definition for "other effective area-based conservation measures" and criteria for their identification and management.

Decision 14/8, in paragraph 9, further invited the IUCN and other expert bodies to continue to assist Parties in identifying OECMs and in applying the scientific and technical advice on criteria for their identification.

\section{Development of these guidelines}

These guidelines have been prepared by the WCPA Task Force on Other Effective Area-based Conservation Measures in response to the request by COP 14 to assist Parties in operationalising Decision 14/8. They are designed for application at various scales, ranging from understanding whether an individual area is an OECM to reporting OECM statistics at the national and global level as a means to assess progress on achieving conservation targets. The development of these guidelines took advantage of work done by the Canadian Council on Ecological Areas to develop guidance on other effective area-based conservation measures (MacKinnon et al., 2015) and is complemented by work on the relationship between Key Biodiversity Areas (KBAs) (IUCN, 2016), protected areas and OECMs led by BirdLife International and partners (Donald et al., 2019).

The primary audiences for these guidelines are Parties to the CBD, government agencies, United Nations (UN) agencies, non-governmental organisations (NGOs), private organisations, indigenous peoples' organisations, local communities and other interested organisations, agencies and individuals involved in understanding, applying, and tracking progress towards achieving Aichi Target 11 and other conservation targets. OECMs will also contribute directly and indirectly towards achievement of several of the UN's Sustainable Development Goals (SDGs). Implementation will further inform the CBD process to develop a post-2020 Biodiversity Framework and achievement of the SDGs, particularly in the context of emerging landscape and seascape approaches to conservation (CBD, 2019). These guidelines apply across the entire terrestrial, freshwater and marine realms. As such they should inform other processes, 
including the discussions on a legally binding treaty to implement marine protected areas on the High Seas.

\section{What these guidelines contain}

These guidelines provide information on how to apply the definition of OECMs at international, national, sub-national or local conservation levels and to report on OECMs to the World Database on Protected Areas and to the CBD. It explains the definition of "other effective area-based conservation measures", along with tools and approaches recommended for identification, recognition, monitoring and reporting. Further sections look at the relationship with other Aichi Biodiversity Targets, the differences between protected areas and OECMs, and how to report to the World Database on Protected Areas (WDPA). Reflecting Decision 14/8, these guidelines show how OECMs are applied within a framework of existing principles set out by the CBD, IUCN and partners, with respect to biodiversity conservation, human rights and sustainable development.

By delivering effective, in-situ conservation of biodiversity, OECMs can contribute to sustaining existing biodiversity values and improving biodiversity conservation outcomes, e.g., by conserving important ecosystems, habitats and wildlife corridors, supporting the recovery of threatened species, maintaining ecosystem functions and securing ecosystem services, enhancing resilience to threats, and retaining and connecting remnants of fragmented ecosystems in degraded landscapes. OECMs can also contribute to ecologically representative and well-connected conservation networks, integrated within wider landscapes and seascapes.

Identification of OECMs and recognition of their governance and management structures provides an opportunity to engage and support a range of new partners in global conservation efforts. In some contexts, this is enabling dialogue about and promoting reconciliation through the appropriate recognition of "Indigenous protected and conserved areas" (Indigenous Circle of Experts, 2018). Recognition as an OECM may also provide additional incentives for conservation and sustainable management of areas of biodiversity significance outside protected areas, such as Key Biodiversity Areas (KBAs), Important Plant Areas (IPAs), Important Bird Areas (IBAs), Important Marine Mammal Areas (IMMAs), and Ecologically or Biologically Significant Marine Areas (EBSAs), noting that such areas must meet the definition of an OECM to be included. The application of these guidelines may also contribute towards enhancing the governance or management of candidate OECMs. 


\section{Definition and characteristics}

This section sets out the definition of an "other effective areabased conservation measure" and provides guidance on each element of the definition.

\subsection{Definition of "other effective area-based conservation measure"}

An "other effective area-based conservation measure" (OECM) is defined by the CBD in Decision 14/8 as:

A geographically defined area other than a Protected Area, which is governed and managed in ways that achieve positive and sustained long-term outcomes for the in situ conservation of biodiversity with associated ecosystem functions and services and where applicable, cultural, spiritual, socio-economic, and other locally relevant values. (CBD, 2018).

The definition of an OECM complements the IUCN definition of a protected area (Dudley, 2008). IUCN defines a protected area as:

A clearly defined geographical space, recognised, dedicated and managed, through legal or other effective means, to achieve the long-term conservation of nature with associated ecosystem services and cultural values.

The distinguishing criterion is that a protected area has a primary conservation objective, whereas an "other effective area-based conservation measure" delivers the effective in-situ conservation of biodiversity, regardless of its objectives.

\section{Box 1}

\section{Identifying or establishing other effective area-based conservation measures}

Protected areas and OECMs are both expected to result in the long-term and effective in-situ conservation of biodiversity. However, whereas protected areas have nature conservation as the primary management objective, OECMs may or may not have nature conservation as an objective.

Types of approaches that deliver effective conservation in other effective area-based conservation measures

1. "Primary conservation" - refers to areas that may meet all elements of the IUCN definition of a protected area, but which are not officially designated as such because the governance authority does not want the area to be recognised or reported as a protected area. For example, in some instances indigenous peoples and local communities may not want areas of high biodiversity value that they govern to be designated as protected areas or recorded in government protected area databases. Assuming an area meets the OECM criteria, the governance authority has the right to withhold or give its consent to the area being recognised as an OECM.

2. "Secondary conservation"-is achieved through the active management of an area where biodiversity outcomes are a secondary management objective. For example, enduring watershed protection policies and management may result in effective protection of biodiversity in watersheds, even though the areas may be managed primarily for objectives other than conservation. Sites managed to provide ecological connectivity between protected areas or other areas of high biodiversity, thereby contributing to their viability, may also qualify as OECMs.

3. "Ancillary conservation"- refers to areas that deliver in-situ conservation as a by-product of management activities, even though biodiversity conservation is not a management objective. For example, Scapa Flow in the Orkney Islands protects shipwrecks and war graves. This protection has led to the ancillary conservation of important biodiversity (see Box 3).

\section{Unrecognised and unreported areas that meet the} definition of a protected area

IUCN recommends that areas that meet all elements of the IUCN definition of a protected area, and are recognised as such by the governance authority, be considered protected areas rather than OECMs (see Figure 1 and Section 4). For example, some privately protected areas are not reported as protected areas by national governments, even though they may satisfy the IUCN criteria.

\section{Other intact natural areas}

All of the above cases must be distinguished from other intact natural areas that are not subject to any deliberate form of conservation management but nevertheless currently harbour intact biodiversity, for example because of their remoteness or due to situations of conflict. These areas are considered to be neither OECMs nor protected areas since such sites may have little long-term security if conditions change, or if they are opened up to environmentally-damaging activities. 


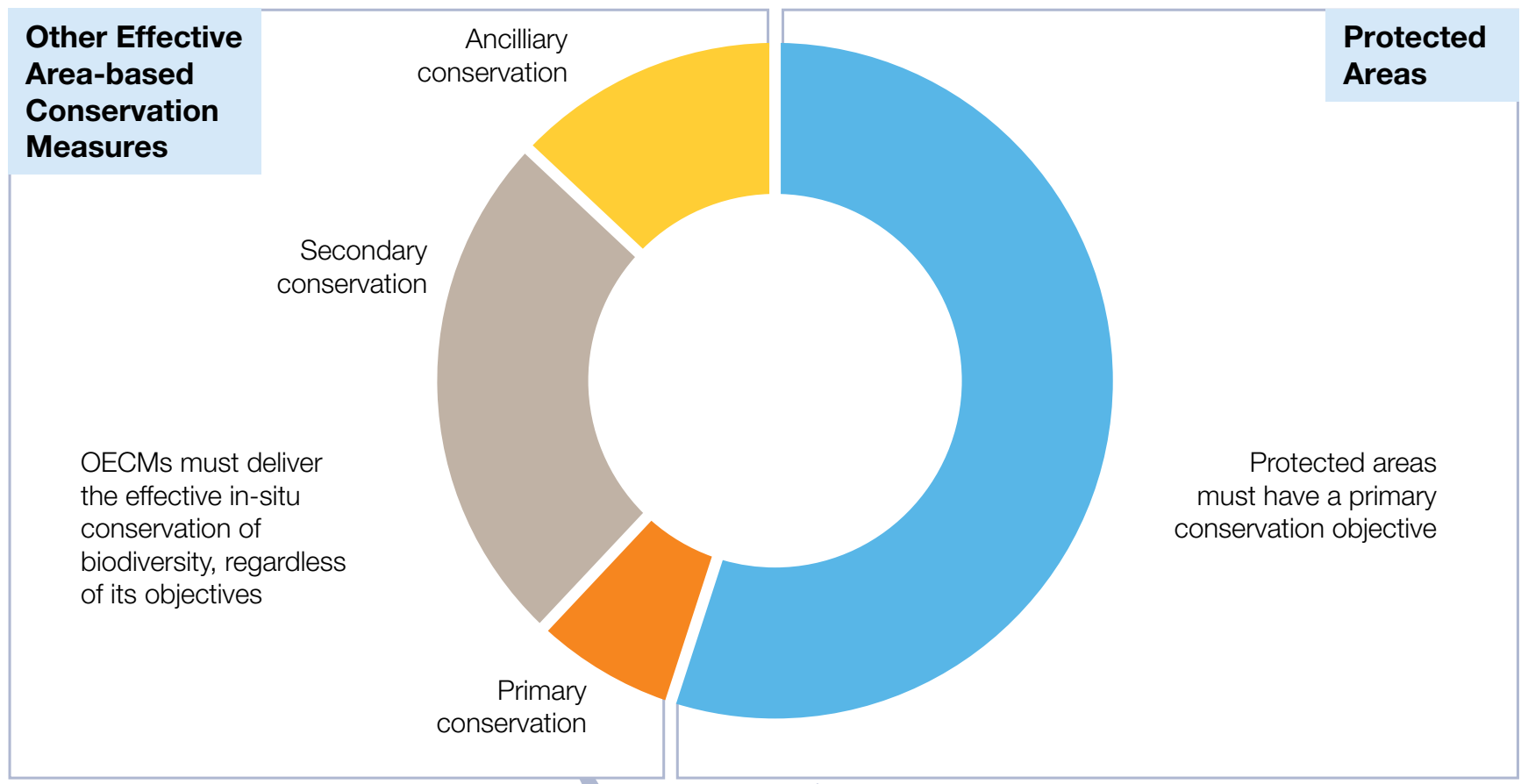

A site with a primary conservation objective would move from OECM to Protected Area if recognised as a protected area by the relevant governance authority

Figure 1. The relationship between OECMs and protected areas (Note: sizes of segments are illustrative only and not based on actual data).

There are several reasons why areas that deliver important in-situ conservation outcomes may not be recognised and reported as protected areas (Borrini-Feyerabend and Hill, 2015) whereas such areas may be recognised through appropriate consent processes as OECMs - see Box 1. Although both protected areas and OECMs contribute towards achievement of Aichi Target 11, they have a number of other important differences.

The relationship between OECMs and protected areas is illustrated in Figure 1, above.

\subsection{Elements of the definition}

The following sub-sections elaborate each element of the overall definition of an "other effective area-based conservation measure":

A geographically defined area other than a Protected Area, which is governed and managed in ways that achieve positive and sustained long-term outcomes for the in situ conservation of biodiversity, with associated ecosystem functions and services and where applicable, cultural, spiritual, socio-economic, and other locally relevant values.

The elements are presented according to the four criteria, as per Decision 14/8.

\section{Criterion A: Area is not currently recognized as a protected area}

\section{a. "other than a Protected Area"}

OECMs can contribute in their own right to area-based targets for terrestrial, freshwater and marine conservation. This means that areas that are already designated as protected areas or lie within protected areas should not also be recognised or reported as OECMs. While protected areas and OECMs are mutually exclusive at any point in time, both protected areas and OECMs have value for biodiversity conservation. Some OECMs may become recognised as protected areas if, for example, nature conservation becomes the primary management objective, or where the area already meets the definition of a protected area and the governing authority now requests its recognition.

\section{Criterion B: Area is governed and managed}

\section{b. "geographically defined area"}

Geographically defined area implies a spatially delineated area with agreed and demarcated boundaries, which can include land, inland waters, marine and coastal areas or any combination of these. In exceptional circumstances, boundaries may be defined by physical features that move over time, such as river banks, the high water mark or extent of sea ice-see Box 2. 
Box 2

\section{A closer look at geographical space}

Geographical space has three dimensions; this requires any governance or management regime for a twodimensional area also to account for the third (vertical) dimension if all the biodiversity of the area is to be effectively conserved in-situ. Designations of protected areas or OECMs will often have limits in the third dimension (e.g. only apply to a certain depth underground or below the water surface, or have an altitude limit to allow passage of commercial aircraft). This has become particularly controversial in marine protected areas, where vertical zoning for commercial purposes undermines conservation outcomes, disrupts ecological connectivity, and creates monitoring and enforcement challenges. For both protected areas and OECMs, the height and depth dimensions need to be consistent with effective conservation management to protect the full range of native biodiversity. In consequence, IUCN has a strong presumption against vertical zoning of OECMs.

While the size of OECMs may vary, they should be of sufficient size to achieve the long-term in-situ conservation of biodiversity, including all ecosystems, habitats and species communities for which the site is important. "Sufficient size" is highly contextual and is dependent on the ecological requirements for the persistence of the relevant species and ecosystems.

\section{c. "governed"}

Governed implies that the area is under the authority of a specified entity, or an agreed upon combination of entities. OECMs can be governed under the same range of governance types as protected areas, namely:

1. Governance by governments (at various levels);

2. Governance by private individuals, organisations or companies;

3. Governance by indigenous peoples and/or local communities; and

4. Shared governance (i.e., governance by various rights holders and stakeholders together) (Dudley, 2008; BorriniFeyerabend et al., 2013).

As with protected areas, the governance of OECMs should be equitable and reflect human rights principles recognised in international and regional human rights instruments and in national legislation, including relating to gender equity and indigenous peoples. Governance mechanisms should be effective in maintaining biodiversity. Any recognition or reporting of OECMs governed by indigenous peoples and/ or local communities should be based on self-identification and requires the free, prior and informed consent of those traditional governance authority(ies) (United Nations, 2007).

\section{d. "managed"}

Managed specifies that the area is being managed in a way that achieves positive and sustained long-term biodiversity conservation outcomes. Relevant authorities, rightsholders and stakeholder should be identified and involved in management.

Unlike protected areas, OECMs do not require a primary objective of conservation, but there must be a direct causal link between the area's overall objective and management and the in-situ conservation of biodiversity over the long-term. "Managed" can include a deliberate decision to leave the area untouched - see the example of historic ship wrecks explained in Box 3.

Management of OECMs should be consistent with the ecosystem approach, with the ability to adapt to achieve expected long-term biodiversity conservation outcomes and to manage emerging new threats (https://www.cbd. int/ecosystem/). Accordingly, the management of OECMs should include "effective means" of control of activities that could impact biodiversity, whether through legal measures or other effective means (such as customary laws or binding agreements with the landowners). To the extent relevant and possible, management should be integrated across OECMs and integrated with surrounding areas.

An area where there is no management regime is not an OECM, even though its biodiversity may remain intact. For example, unmanaged areas of the high seas, areas under military conflict, and other areas currently in a natural or near-natural state should not be considered as OECMs in the absence of a management regime that provides effective and enduring in-situ biodiversity conservation. Management regimes can include deliberate decisions to leave the area untouched.

\section{Criterion C: Achieves sustained and effective contribution to in situ conservation of biodiversity}

\section{e. "positive outcomes" for biodiversity conservation (termed "effective" in the criteria of CBD decision 14/8)}

OECMs should be effective at delivering positive and sustained outcomes for the in-situ conservation of biodiversity. Specifically, there should be a clear association between the management and biodiversity outcomes, with mechanisms in place to address existing or anticipated threats (see Mathur et al., 2017 for guidance on identifying and managing threats).

Environmentally-damaging industrial activities and infrastructure development should not occur in OECMs. This is consistent with IUCN Recommendation 102 (WCC-2016Rec-102-EN), adopted at the World Conservation Congress 2016 in Hawai'i. This recommendation calls on governments and relevant authorities "to adopt and implement policies that restrict environmentally-damaging industrial activities and infrastructure development that may have negative impacts on any areas of particular importance for biodiversity and ecosystem services that are identified by governments as essential to achieving the Aichi Biodiversity Targets". Environmentally-damaging industrial activities include, for example, industrial fishing and forestry, mining, oil and gas extraction, industrial agriculture, and environmentally- 
Box 3

\section{Historic wreck sites e.g. Scapa Flow-an example of Ancillary Conservation}

Strict protection of historic wreck sites for cultural and historical reasons is a common feature in many ocean basins around the world. This purpose coincidentally provides protection of associated marine habitats, species and ecosystems. There are extensive examples in the Caribbean and Pacific Ocean as a legacy of historical conflicts across the ages. In the UK, Scapa Flow is perhaps the best-known example of where such "ancillary conservation" is achieved.

Scapa Flow is a natural harbour off mainland Orkney in the North of Scotland. The area is under the jurisdiction of the Orkney Islands Harbour Authority whose management objectives for the area are the safe management of the harbour whilst at the same time conserving the site's cultural heritage. The area is known for the wrecks of First World War German warships that were scuttled within the Harbour and that of the Royal Oak, the Second World War flagship of the Royal Navy, which was sunk by a German U-Boat and is a designated war grave.

Scapa Flow covers an area of $324.5 \mathrm{~km}^{2}$ and contains in the order of 1 billion cubic metres of water. The strict protection afforded to its historical wrecks also coincidentally provide a high degree of protection to the benthic ecosystem, evidenced by thriving maerl beds, flame shell beds, horse mussel reefs and fan shells which are very rare elsewhere in Scotland. Although the area is not managed with a specific objective of nature conservation, protection of the site's biodiversity is achieved through ancillary conservation. In February 2019, Scotland's First Minister, Nicola Sturgeon, announced a consultation on two new "historic" MPAs in Scotland, one of which is Scapa Flow. If approved this would demonstrate the close relationship between OECMs and protected areas. damaging infrastructure, such as dams, roads and pipelines. These threats should be avoided. This applies both to environmentally-damaging activities inside OECMs and also to those outside the area but impacting on the OECMs.

\section{f. "sustained long-term"}

The governance and management of OECMs is expected to be sustained and deliver the long-term effective insitu conservation of biodiversity. Short-term or temporary management strategies do not constitute an OECM. For example, a commercial fishing closure that stays in place only until an overfished area recovers, is not an OECM. IUCN's guidance is that the factors that govern and manage an OECM should be expected to be ongoing and for the long-term.

Effective conservation outcomes may arise from strict protection or certain forms of sustainable management consistent with the CBD definitions of "in-situ conservation" and "biodiversity". However, most areas managed for industrial production, even if they have some biodiversity benefits, should not be considered as OECMs. Sustainablymanaged commercial fisheries and commercial forests, for instance, should be reported under Aichi Targets 6 and 7, respectively, or other appropriate targets.

On the other hand, sites with a range of management approaches, including seasonal arrangements (e.g. sites managed for migratory bird species) may qualify as OECMs if the seasonal measures are part of a long-term overall management regime that results in the year-round in-situ conservation of biodiversity for which the site is important. In some cases short-term regulatory instruments, renewed continuously, may provide de facto long-term measures.

Management of OECMs should be consistent with an ecosystem and precautionary approach, with the ability to adapt to maintain biodiversity outcomes in the long-term and to address potential new threats. Practical steps should be in place for monitoring and reporting on the effectiveness of OECMs (see Section 4).

\section{g. "in-situ conservation of biodiversity"}

The CBD defines in-situ conservation, with respect to biodiversity, as:

The conservation of ecosystems and natural habitats and the maintenance and recovery of viable populations of species in their natural surroundings and, in the case of domesticated or cultivated species, in the surroundings where they have developed their distinctive properties. (CBD Article 2).

Other effective area-based conservation measures should deliver biodiversity outcomes of comparable importance to, and complementary with, those of protected areas. This includes their contribution to ecological representation, coverage of areas important for biodiversity and associated ecosystem functions and services, connectivity and integration in wider landscapes and seascapes, as well as management effectiveness and equity requirements.

\section{OECMs are expected to achieve the conservation of} nature as a whole, rather than only selected elements of biodiversity. The CBD definitions of "biodiversity" and "in-situ conservation" clearly recognise that a single species can only exist in-situ as part of an interconnected web with other species and the abiotic environment. Therefore conservation measures targeting single species or subsets of biodiversity should not allow the broader ecosystem to be compromised. Recognising the linkage between biological and geological diversity, "geodiversity" may also be an important management focus in OECMs (Zarnetske et al., 2019).

\section{h. "biodiversity"}

Given the explicit link between OECMs and biodiversity conservation outcomes, it is a clear requirement that OECMs must achieve the effective and sustained in-situ conservation of biodiversity. While approaches for identifying 


\section{A closer look at biodiversity}

OECMs should effectively protect one or more of the following elements of native biodiversity:

- Rare, threatened or endangered species and habitats, and the ecosystems that support them, including species and sites identified on the IUCN Red List of Threatened Species, Red List of Ecosystems, or national equivalents.

- Representative natural ecosystems.

- Areas with a high level of ecological integrity or ecological intactness, which is characterised by the occurrence of the full range of native species and supporting ecological processes. These areas will be intact or being restored under the proposed management regime.

- Range-restricted species and ecosystems in natural settings.

- Important species aggregations, including during migration or spawning.

- Ecosystems especially important for species life stages, feeding, resting, moulting and breeding.

- Areas of importance for ecological connectivity or that are important to complete a conservation network within a landscape or seascape.
- Areas that provide critical ecosystem services, such as clean water and carbon storage, in addition to in-situ biodiversity conservation.

- Species and habitats that are important for traditional human uses, such as native medicinal plants, in addition to in-situ biodiversity conservation.

In this context, an intensively-managed farm with a small proportion of the original native plants and birds will likely not be an OECM. Conversely, an area of native grassland, dominated by native plants, and having healthy populations of a large variety of native birds and mammals, might well be an OECM if a lower-intensity management and governance regime ensures these outcomes over the long-term. Just as for protected areas, there may be instances where an OECM is especially important for protecting a particular threatened species by protecting the entire ecosystem.

As climate change alters ecosystems, understanding of what is natural and effective in a particular place may also change. OECMs may need to be recognised and managed with adaptation to climate change in mind (Gross et al., 2016). the important biodiversity elements of such areas vary according to national, subnational, and local circumstances, global guidance now exists for identifying Key Biodiversity Areas (IUCN, 2016) and for describing areas such as Ramsar Sites and Ecologically and Biologically Significant Marine Areas (Dunstan, 2016). The biodiversity conserved by an OECM can occur in areas within and beyond national jurisdiction.

Recognition of an OECM should include the identification of the range of biodiversity attributes for which the site is considered important and be based upon the best available knowledge-see Box 4. These key biodiversity values, as well as the broader conservation values of OECMs, should be described and tracked over time.

\section{Criterion D: Associated ecosystem functions and services and cultural, spiritual, socio-economic and other locally relevant values}

\section{i. "ecosystem functions and services"}

Healthy and functioning ecosystems provide a range of services. Ecosystem functions are an integral part of biodiversity, and are defined as the biological, geochemical and physical processes that take place or occur within an ecosystem. Ecosystem services include provisioning services such as food and water; regulating services such as regulation of floods, drought, land degradation and disease; and supporting services such as soil formation and nutrient recycling. Protection of these ecosystem functions and services may be a frequent rationale for the recognition of OECMs. However, management to enhance one particular ecosystem service should not impact negatively on the site's overall biodiversity conservation values.

\section{j. “cultural, spiritual, socio-economic, and other locally relevant values"}

OECMs include areas where the protection of key species and habitats and management of biodiversity may be achieved as part of cultural, spiritual socio-economic and other locally relevant values and practices. In such cases, it will be essential to ensure the recognition and protection of the linkages between biological and cultural diversity and associated governance and management practices that lead to positive biodiversity outcomes, such as customary sustainable uses of biodiversity (CBD Article 10(c)). Conversely, management for cultural, spiritual socio-economic or other locally relevant values within an OECM should not impact negatively on biodiversity conservation values. 


\section{Identifying other effective area-based conservation measures in practice}

In-situ conservation of biodiversity is "fundamental" to stemming biodiversity loss (CBD, 1992). Protected areas and OECMs are the primary means of achieving in-situ conservation under Aichi Target 11 and will continue to be important features of post-2020 CBD targets. All efforts to conserve biodiversity are valuable, but only those areabased measures that contribute directly to long-term in-situ conservation should be considered for reporting toward in-situ conservation targets such as Aichi Target 11. Other conservation efforts, including area-based approaches aimed at sustainable use, will be more appropriately reported against other types of targets, such as Aichi Targets 6 (sustainable fisheries) and 7 (sustainable forestry and agriculture) or analogous post-2020 targets (see, for example, Laffoley et al., 2017 or Appendix I). Identifying and reporting OECMs will contribute to any CBD targets for in-situ conservation, including Aichi Target 11 and targets for in-situ conservation adopted post-2020.

To support decision-making processes, WCPA has developed a simple four-step screening tool, directly linked to the definition and the explanation of terms in Section 2. Any area being considered for recognition as an OECM should first be screened for its eligibility against these criteria by or with the consent of the governing authority.

\subsection{Screening tool}

The screening tool (see Box 6) applies four tests to determine whether an area qualifies as a candidate OECM.

- Test 1. Ensure that the area is not already recognised and/ or recorded as a protected area.

- Test 2. Ensure that the area has the essential characteristics as defined for OECMs.

- Test 3. Ensure that the conservation outcome will endure over the long-term.

- Test 4. Ensure that an in-situ area-based conservation target (e.g., Aichi Target 11), as opposed to a sustainable use target, is the right focus for reporting.

The elements of each test are elaborated in Section 3.2. An area must pass all four screening tests to be considered as a candidate OECM.

\section{Box 5}

\section{Using the screening tool-key points to address}

There are seven important points to consider and address when applying the screening tool:

1. For cases in which a party other than the governing authority is managing the process-including potential OECMs governed by indigenous peoples and local communities, to whom the principle of free, prior and informed consent applies-confirm the interest of the governing authority in having the area evaluated and potentially reported as an OECM.

2. Thoroughly read and discuss the guidelines and the screening criteria and assemble a review team consisting of people familiar with the diversity of approaches being taken at the relevant scale to area-based conservation in that location.

3. Prior to applying the screening tool (section 3.2), compile a comprehensive set of maps and information on possible locations that might qualify as an OECM having compared them to maps of known designated or proposed protected areas so the relationship is readily understood.

4. Apply each of the four screening tests to each area being assessed as an OECM.

5. Identify those areas that pass all four tests as candidate OECMs and assess them using a nationally-adapted and empirical-based assessment tool (Section 3.3).

6. Report OECMs which pass the assessment process to the WDPA - see section 4.

7. For those areas that do not pass the tests, record reasons for decisions against each criterion. This information may be helpful in identifying whether any changes to the governance or management might lead to the area qualifying as an OECM. Where desired, reapply 1-5 above, as appropriate. 


\subsection{Applying the screening tool}

This section provides guidance on how to apply the screening tool. All references to "elements" refer to the elements of the definition, described in Section 2.2.

\section{Test 1. Ensure that the area is not already recognised and/or recorded as a protected area}

The area is neither already recognised nor proposed as a marine, freshwater or terrestrial protected area (see element a).

Test 2. Ensure that the area has the essential characteristics as defined for OECMs.

1. Location: The area must be a geographically-defined space. Wider measures for species and/or environment that are not "area-based" fail this test. For example, species-specific national or regional hunting bans and regulations, whale-watching rules, or temporary fishing closures (see element $b$ ) are regional species-specific measures and not in-situ area-based conservation.

2. Sustained governance and management: The area is governed and managed, and such arrangements are expected to be ongoing and sustained over the long-term. There should be a direct causal link between: (i) the area's overall governance, objective(s) and management and (ii) the in-situ conservation of biodiversity over the long-term. Areas where there is neither a governance authority nor any management are not OECMs (see elements $c, d$ and f). Accordingly, an area currently in a natural or near-natural state is not automatically an OECM.

3. Effective in-situ conservation of biodiversity: The area delivers the effective in-situ conservation of biodiversity, with associated ecosystem functions and services. There should be a clear understanding that the area is effectively conserving native biodiversity and the ecosystem processes that support biodiversity. This may be achieved through a variety of governance types and management practices, including those associated with cultural, spiritual, socio-economic and other locally relevant values. Areas that deliver conservation outcomes only over the short term or areas that are intended or offer potential to conserve nature but do not yet deliver conservation outcomes do not qualify as OECMs (see elements e, $g, h$, $i$, and $j$.

4. The area is free of environmentally-damaging activities and threats to biodiversity can be managed under the existing governance and management systems.

Test 3. Ensure that the conservation outcome will endure over the long-term.

This refers to the probability of the conservation outcome being maintained over the long term through legal or other effective means (such as, customary laws or formal agreements with landowners, see element $e$ and $f$ ). This test emphasises the difference between current conservation efforts that can be reversed easily and an OECM that can sustain conservation outcomes over the long term.

Test 4. Ensure that an in-situ area-based conservation target (e.g., Aichi Target 11), as opposed to a sustainable use target, is the right focus for reporting.

In-situ conservation of biodiversity is one of the three primary objectives of the CBD. Within the context of reporting to the CBD under the 2020 Aichi Biodiversity Targets, protected areas and OECMs are the primary means of achieving insitu conservation and the primary focus of Aichi Target 11. As elaborated in Box 6, area-based measures may also be applied to achieve sustainable use of the components of biodiversity (the focus of, for example, Aichi Target 6 on sustainable fisheries and Aichi Target 7 on sustainable agriculture, aquaculture and forestry). Yet it is important not to confuse such measures with in-situ conservation measures relevant to Aichi Target 11. Beyond 2020, it will continue to be important to report in-situ conservation measures (protected areas and OECMs) against their appropriate targets, and sustainable use measures against theirs. See Appendix I on the relationship between Target 11 and other associated Targets and Appendix II for a decision tree on selecting the most appropriate Aichi Target for a given conservation measure.

\section{Areas that pass all four tests can be considered to be candidate OECMs.}

\subsection{Assessment}

Areas that are considered to be candidate OECMs should then be subject to more detailed review involving empirical evidence, conducted on a case-by-case basis. The OECM Assessment Methodology is available for download from the following link: https://www.iucn.org/theme/protectedareas/wcpa/what-we-do/oecms

Only those areas that pass this empirical assessment, including the full and effective consent and participation of the governance authority, should be reported to the WDPA (see Section 4 and Appendix III).

\subsection{Examples of potential other effective area-based conservation measures}

The following situations can be considered as potential OECMs. These examples cover the range of governance types for purposes of illustrating their applicability. A number of examples in which the citation has been marked with an asterisk (*) can be found in a Special Issue of PARKS journal on OECMs (IUCN/WCPA, 2018). https://parksjournal.com/ list-of-papers/ 


\section{Ensuring that Aichi Target 11 is the right focus}

The Strategic Plan for Biodiversity 2011-2020 and the 20 Aichi Biodiversity Targets call for a comprehensive set of approaches to stem biodiversity loss, including raising awareness of biodiversity, eliminating perverse incentives for its degradation, implementing sustainable production plans, reducing habitat loss, preventing species extinction, reducing direct pressures on biodiversity to sustainable levels, and conserving biodiversity in-situ.

Area-based conservation measures can contribute to the achievement of several Aichi Targets, but not all areabased measures achieve their objectives through the insitu conservation of biodiversity consistent with Target 11 criteria.

For example, many fisheries closures apply to specific geographic areas and therefore are area-based measures, but may only be closed to the fishing of specific depleted commercial fish species, the use of certain habitat-damaging or non-selective gear types, or at certain times of year when vulnerable species are present at a vulnerable life stage (e.g., spawning aggregations). They may continue to allow fishery and non-fishery activities (e.g., seismic testing, oil drilling), as long as such activities do not compromise the purposes for which they have been established. As such, they may be effective tools in helping to ensure that fisheries are managed sustainably (the objective of Aichi Target 6), without achieving the in-situ conservation of biodiversity (the objective of Aichi Target 11).

Similarly, forestry management plans are applied on an area basis and may vary in their degree of ecological impact. Lower-impact approaches may retain more species, habitat structures, and ecosystem functions than higher-impact approaches, and some may indeed achieve the CBD meaning of "sustainable use"-i.e., the use of components of biological diversity in a way, and at a rate, that does not lead to the long-term decline of biological diversity. However, because of their extractive, ecosystem-altering impacts, they may not also achieve the in-situ conservation of all biodiversity. Such measures might best be considered as contributions to Aichi Target 7 , which calls for areas under forestry to be managed sustainably by 2020 .

The threshold between a Target 7 and a Target 11 measure may be difficult to decide in cases of customary use of biological resources in largely natural settings by indigenous peoples and local communities. In such cases, it may be useful to look at how well protected such areas are from forestry and non-forestry threats alike over the long-term to determine whether an area is an OECM.

Other Aichi Targets for which area-based measures may frequently be employed include Target 10 (minimize multiple anthropogenic threats on coral reefs), Target 12 (prevent the extinction and improve the conservation status of threatened species), Target 14 (restore and safeguard ecosystems that provide essential services), and Target 15 (conserve and restore degraded ecosystems). Where such measures achieve their objectives through the long-term in-situ conservation of biodiversity, they may also contribute to Target 11 .

\section{Primary conservation}

A site that has a primary conservation objective and delivers effective biodiversity conservation but is not reported as a protected area could be recognised as an OECM if the governance authority so wishes.

\section{Examples can include:}

- Some territories or areas (marine, freshwater or terrestrial) governed by indigenous peoples, local communities or private entities that have a primary and explicit conservation objective and deliver the in-situ conservation of biodiversity, but where the governing body wishes the territories or areas to be recognised and reported as OECMs, rather than as protected areas.

- Privately conserved areas, which are managed with a specific conservation objective but which are not recognised as protected areas under national legislation (Mitchell et al., 2018), e.g. ecosystem restoration areas in Indonesia (Utomo and Walsh, 2018*).
- Areas that include Key Biodiversity Areas, managed in ways that deliver long-term in-situ conservation of biodiversity through, for example, regulation or other effective approaches.

- Some permanently set-aside areas of a managed forest, such as old-growth, primary, or other high-biodiversity value forests, which are protected from both forestry and nonforestry threats.

- Some natural areas managed by universities for biological research.

\section{Secondary conservation}

\section{Examples can include:}

- Territories and areas managed by indigenous peoples and/ or local communities (ICCAs, or sections of these areas) to maintain natural or near-natural ecosystems, with low levels of use of natural resources practised on a sustainable basis and in a way that does not degrade the area's biodiversity. This includes coastal and marine areas where local community-based harvesting and management practices 
result in de facto conservation of fish populations, habitats and other associated marine biodiversity such as some locally managed marine areas (LMMAs) (Jupiter et al., 2014).

- Traditional management systems that maintain high levels of associated biodiversity. These could include certain agricultural or forest management systems that maintain native species and their habitat (e.g. Eghenter, 2018; Mwamidi et al., 2018*).

- Urban or municipal parks managed primarily for public recreation but which are large enough and sufficiently natural to also effectively achieve the in-situ conservation of biodiversity (e.g. wild grassland, wetlands) and which are managed to maintain these biodiversity values (e.g. Gray et al., 2018).

- Military lands and waters, or portions of military lands and waters that are primarily managed for the purpose of defence, but with specific secondary objectives focused on the conservation of biodiversity. Canadian Forces Base Shilo, located in the mixed-grass prairie ecosystem of south-central Manitoba (Canada), was proposed by Canada as an OECM in 2019.

- Watersheds or other areas managed primarily for water resource management that also result in the in-situ conservation of biodiversity. This can include, for example, water meadows, riverine forest, coastal forests, wetlands, streams, upland catchments, or other areas managed for long-term soil and slope stabilisation, flood mitigation, or other ecosystem services (e.g. Matallana-Tobón et al., 2018*).

- Permanent or long-term fisheries closure areas designed to protect complete ecosystems for stock recruitment, to protect specialised ecosystems in their entirety, or protect species at risk through the in-situ conservation of biodiversity as a whole, and are demonstrated to be effective against fishery and non-fishery threats alike.

- Hunting reserves that maintain natural habitats and other flora and fauna as well as viable populations of hunted and non-hunted native species.

- Areas successfully restored from degraded or threatened ecosystems, to provide important ecosystem services but which also contribute to effective biodiversity conservation, e.g. freshwater and coastal wetlands restored for flood protection.

- Areas that contribute to conservation because of their role in connecting protected areas and other areas of particular importance for the conservation of biodiversity, thereby contributing to the long-term viability of larger ecosystems (e.g. Waithaka \& Warigia Njoroge, 2018*).

\section{Ancillary conservation}

\section{Examples can include:}

- Sacred natural sites with high biodiversity values that are conserved in the long-term for their associations with one or more faith groups (e.g. Matallana-Tobón et al., 2018*).

- Coastal and marine areas protected for reasons other than conservation, but that nonetheless achieve the insitu conservation of biodiversity e.g., historic wrecks, war graves, etc. (e.g. see Box 3)
- Military lands and waters, or portions of military lands and waters that are managed for the purpose of defence, do not have a secondary objective of biodiversity conservation, but achieve the effective conservation of biodiversity in the long term.

\subsection{Examples of areas unlikely to meet the criteria}

\section{The following areas and management regimes are unlikely to qualify as OECMs:}

- Small, semi-natural areas within an intensively-managed landscape with limited biodiversity conservation value, such as municipal parks, formal/domestic gardens, arboreta, field margins, roadside verges, hedgerows, narrow shoreline or watercourse setbacks, firebreaks, recreational beaches, marinas and golf courses.

- Forests that are managed commercially for timber supply and are intended for logging, even though they may have some conservation values and support some species of interest. Such areas should be considered as contributing to Aichi Target 7.

- Fishery closures, and other spatial fisheries management tools, including, but not limited to, fishing quotas or catch limits, temporary set asides or gear restriction areas with a single species, species group, or habitat focus, that may be subject to periodic exploitation and/or be defined for stock management purposes, and that do not deliver insitu conservation of the associated ecosystems, habitats and species with which target species are associated. Such areas should be considered as contributing to Aichi Target 6.

- Agricultural lands which are managed in a manner that limits the in-situ conservation of biodiversity. This may include, for example, pastures that are grazed too intensively to support native grassland ecosystems or species, or grasslands replanted with monocultures or non-native species for the purposes of livestock production.

- Temporary agricultural set asides, summer fallow and grantmaintained changes to agricultural practice that may benefit biodiversity.

- Conservation measures that apply to a single species or group of species, over a wide geographical range such as hunting regulations or whale-watching rules; these are better considered as being part of wider species conservation measures (Targets 5, 6, 7 and/or 12).

The above examples are not meant to be exhaustive or without exception, but are intended to indicate which kinds of areas may qualify as OECMs and which would not. When considering any area, the definitions and criteria applied during the four criteria screening test will be the appropriate route to ensure consistent identification of candidate OECMs. Given the diversity of situations where OECMs can occur,

it is essential that all areas being assessed should be screened carefully to evaluate each specific case.

The concept of OECMs will generally be used to recognise existing examples of effective area-based conservation and 
the governance and management regimes that support them. The concept could, however, also be used to promote new and additional conservation efforts. During negotiation of Decision 14/8, qualifying terms like "have a significant biodiversity value, or have objectives to achieve this" and "achieve, or is expected to achieve, positive and sustained outcomes for the in-situ conservation of biodiversity" were added to guiding text for identification of OECMs. Governments proposing these caveats stressed that they were added to address sites where restoration was taking place, to acknowledge deliberate attempts at ecosystem recovery. The intent to restore ecosystems and habitats is commendable,

but restoration areas should not be recognized as OECMs until they are delivering demonstrable and significant biodiversity outcomes - see Box 7 .

\subsection{Rights and responsibilities of governance authorities}

There are many diverse reasons that will lead a governance authority to consider recognising their area as an OECM. Governance authorities can identify an area as a possible OECM and either assess it themselves or seek independent support to determine whether the area qualifies as an OECM using these guidelines. They have the right to object to the external nomination or recognition of their area as an OECM in cases where their consent has not been given. This applies to all four governance types, as set out above (see element $c$ ). When an area is recognised as an OECM, it places a heightened responsibility on the governance authority to continue to govern and manage the area in ways that achieve the in-situ conservation of biodiversity.

\subsection{Supporting OECMs}

Recognition of other effective area-based conservation measures should be supported by measures to enhance the governance capacity of their legitimate authorities and secure their positive and sustained outcomes for biodiversity. While national circumstances will differ, any related legislation should provide greater support and recognition to existing governance systems and not seek to supplant or unnecessarily alter those local arrangements that are effective.

\section{Box 7}

\section{Ecological restoration in OECMs}

Ecological restoration is the process of managing or assisting the recovery of an ecosystem that has been degraded, damaged or destroyed as a means of sustaining ecosystem resilience and conserving biodiversity (CBD, 2016). It is likely to become a more common and necessary conservation tool in the future.

\section{Areas proposed for, or under active restoration} efforts, should not be recognised as OECMs until they are delivering demonstrable and significant biodiversity outcomes. IUCN's guidance is therefore that restoration areas proposed as OECMs should meet all the following conditions:

1. Restoration is taking place in an ecosystem of high biodiversity value (see Box 4) so that the area, once restored, will qualify as an OECM by virtue of its conservation value and contribution to strengthening existing protected area networks;

2. Any restoration efforts should (i) have reduced the threats that caused the original degradation and biodiversity loss, (ii) show successful ecosystem recovery based on the principles of ecological restoration and (iii) contribute to long-term maintenance of a resilient and evolving ecosystem; and

3. Demonstrate active ecological restoration or natural regeneration of a type and at a scale that is expected to regain and maintain ecological integrity and a full complement of species. 


\section{Monitoring and reporting other effective area-based conservation measures}

Monitoring the effectiveness of OECMs is needed. This should include: (i) baseline documentation and ongoing monitoring of the sites' biodiversity values; (ii) ongoing community-based monitoring, participatory mapping and incorporation of traditional knowledge, where appropriate; (iii) monitoring conservation actions, including those focused on sustaining biodiversity and improving in situ conservation; and (iv) monitoring of governance, stakeholder involvement and management systems that contribute to the biodiversity outcomes (Haase et al., 2018; Woodley et al., 2015).

A key element of the definition is that OECMs should be "governed and managed in ways that achieve positive and sustained long-term biodiversity outcomes". This is linked to the concept of management effectiveness. Therefore, monitoring and reporting on the effectiveness of OECMs will be critical to ensure that sites continue to deliver conservation outcomes (Woodley et al., 2015). Measuring Protected Area Management Effectiveness (PAME) will in many cases be the most pragmatic way to measure the effectiveness of OECMs, but the PAME tools should be supported by additional quantitative information on biodiversity outcomes. The use of the IUCN Green List of Protected and Conserved Areas Standard will further support such documentation (IUCN, 2017). Authorities responsible for OECMs should ensure that adequate monitoring is undertaken of the effectiveness of management to ensure long-term conservation outcomes (see Hockings et al., 2015). This information should also be reported to UNEP-WCMC for integration into the Global Database on Protected Area Management Effectiveness (GD-PAME).

The concept of "other effective area-based conservation measures" is a product of decisions by the Parties to the CBD. When adopting the definition of OECMs, the CBD COP14 also encouraged parties to submit data on OECMs to the World Database on Protected Areas (WDPA) managed by UNEP-WCMC (CBD, 2018). In order to fulfil this obligation, UNEP-WCMC has established a parallel database for OECMs under the Protected Planet initiative, to complement the WDPA. The Protected Planet initiative encompasses several databases that can be accessed and downloaded through its website, www.protectedplanet.net. UNEP-WCMC uses data in these databases to measure progress against international conservation goals, such as Aichi Biodiversity Target 11 and Sustainable Development Goals 14 and 15.

Area-based measures that qualify as protected areas or OECMs should be reported to the WDPA or OECM database, respectively. Such reporting should be done with the free, prior and informed consent of the relevant governance authorities.

For more information on reporting requirements to the WDPA and OECM database and verification of data, see Table 1 (below), Appendix III and the guidance available from www.wcmc.io/oecm_guidance.

Table 1. Basic principles for verification of data for inclusion in the Protected Planet databases

\begin{tabular}{l|l}
$\begin{array}{l}\text { Data submitted } \\
\text { by governmental } \\
\text { sources }\end{array}$ & $\begin{array}{l}\text { In line with the official mandates for the WDPA, data submitted by governmental sources on } \\
\text { protected areas or OECMs will be considered as state verified and will be included in the WDPA } \\
\text { and OECM databases after data formatting and quality control. }\end{array}$ \\
\hline $\begin{array}{l}\text { Data submitted by } \\
\text { non-governmental } \\
\text { sources }\end{array}$ & $\begin{array}{l}\text { Incoming data from non-government data providers undergoes a verification process before } \\
\text { being added to the Protected Planet databases. } \\
\text { Data can be verified either by state verifiers or by expert verifiers. If neither party can verify the } \\
\text { data, it does not enter the Protected Planet databases. }\end{array}$ \\
\hline $\begin{array}{l}\text { Resolution of } \\
\text { conflicting data }\end{array}$ & $\begin{array}{l}\text { Where there is conflict between the opinions of the data provider and data verifier (for example, } \\
\text { disputes over the correct boundary of a site), this will be discussed with both parties in an } \\
\text { attempt to reach a solution. } \\
\text { Data providers are made aware of the verification process when submitting data, and are kept } \\
\text { informed of its progress. In cases where no resolution can be found, data cannot enter the } \\
\text { Protected Planet databases. }\end{array}$ \\
\hline $\begin{array}{l}\text { Frequency of data } \\
\text { verification }\end{array}$ & \begin{tabular}{l} 
UNEP-WCMC aims to update all data at least once every five years. \\
\hline
\end{tabular}
\end{tabular}

For queries regarding reporting, please contact: protectedareas@unep-wcmc.org. 


\section{References}

Borrini-Feyerabend, G., Dudley, N., Jaeger, T., Lassen, B., Pathak Broome, N., Phillips, A. and Sandwith, T. (2013). Governance of Protected Areas: From understanding to action. Best Practice Protected Area Guidelines Series No. 20. Gland, Switzerland: IUCN.

Borrini-Feyerabend, G. and Hill, R. (2015). 'Governance for the conservation of nature', in Worboys, G. L., Lockwood, M., Kothari, A., Feary, S. and Pulsford, I. (eds) Protected Area Governance and Management, pp. 169-206. ANU Press: Canberra.

Canada Department of Fisheries and Oceans (2016). Operational guidance for identifying "other effective area-based conservation measures" in Canada's marine environment. Canada Department of Fisheries and Oceans: Ottawa, Canada. 9pp. Accessed January 17, 2017 at:

http://www.dfo-mpo.gc.ca/oceans/documents/publications/ oeabcm-amcepz/2016_11_24_OEABCM-marine-guidancefor-public-audience_Version-1b.pdf

Convention on Biological Diversity (CBD) (1992). Convention on Biological Diversity. https://www.cbd.int/convention/text/

CBD (2010). Strategic Plan on Biodiversity 2011-2020. https://www.cbd.int/sp/

CBD (2012). Decision on Protected Areas (Xl/24). https:// www.cbd.int/doc/decisions/cop-11/cop-11-dec-24-en.pdf

CBD (2016). Progress Towards the Achievement of Aichi Biodiversity Targets 11 and 12 (Decision XIII/2). https://www. cbd.int/doc/decisions/cop-13/cop-13-dec-02-en.pdf

CBD (2016). Ecosystem restoration: short-term action plan. CBD/COP/DEC/XIII/5, 10 December 2016. https://www.cbd. int/doc/decisions/cop-13/cop-13-dec-05-en.pdf

CBD (2018). Protected areas and other effective area-based conservation measures (Decision 14/8). https://www.cbd.int/ doc/decisions/cop-14/cop-14-dec-08-en.pdf

CBD (2019). Post-2020 Global Biodiversity Framework: Discussion Paper. https://www.cbd.int/doc/c/d431/ b38f/3d580bb73e7c2b5aaa286310/post2020-prep-01-01en.pdf

Day, J., Dudley, N., Hockings, M., Holmes, G., Laffoley, D., Stolton, S. and Wells, S. (2012). Guidelines for applying the IUCN Protected Area Management Categories to Marine Protected Areas. IUCN: Gland, Switzerland.

Donald, P., Buchanan, G.M., Balmford, A., et al. (2019). 'The prevalence, characteristics and effectiveness of Aichi Target 11 's "other effective area-based conservation measures" (OECMs) in Key Biodiversity Areas'. Conservation Letters. 2019;e12659. https://doi.org/10.1111/conl.12659

Dudley, N. (Ed) (2008). Guidelines for Applying Protected Area Management Categories. IUCN: Gland, Switzerland. 86pp. https://doi.org/10.2305/IUCN.CH.2008.PAPS.2.en

Dunstan, P. K., Bax, N.J., Dambacher, J.M., Hayes, K.R., Hedge, P.T., Smith, D.C., and Smith, A.D.M. (2016). 'Using ecologically or biologically significant marine areas (EBSAs) to implement marine spatial planning'. Ocean \& Coastal Management, 121, 116-127.
Eghenter C. (2018). 'Indigenous effective area-based conservation measures: conservation practices among the Dayak Kenyah of North Kalimantan'. PARKS 24. IUCN: Gland.

Gray, M. (2004). Geodiversity: Valuing and Conserving Abiotic Nature. John Wiley and Sons: UK.

Gray, P.A., Cheriton, D., Gaetz, N., Lehman, P., Sherwood, J., Beechey, T. J. and Lemieux C.J. (2018). 'Comparing screening tools for assessment of potential 'other effective area-based conservation measures' in Ontario, Canada'. PARKS 24. IUCN: Gland.

Gross, J.E., Woodley, S., Welling, L.A., and Watson, J. (eds.) (2016). Adapting to Climate Change: Guidance for protected area managers and planners. Best Practice Protected Area Guidelines Series No. 24. IUCN: Gland, Switzerland. https:// portals.iucn.org/library/node/46685

Haase, P., Tonkin, J.D., Stoll, S., Burkhard, B., Frenzel, M., Geijzendorffer, I.L., Häuser, C. et al. (2018). 'The next generation of site-based long-term ecological monitoring: Linking essential biodiversity variables and ecosystem integrity'. Science of the Total Environment 613: 1376-1384.

Indigenous Circle of Experts, (2018). We Rise Together: Achieving Pathway to Canada Target 1 through the creation of Indigenous Protected and Conserved Areas in the spirit and practice of reconciliation. Indigenous Circle of Experts, Pathway to Canada Target 1.

Hockings, M., Leverington, F. and Cook, C. (2015).

'Protected area management effectiveness', in Worboys, G. L., Lockwood, M., Kothari A., Feary S. and Pulsford I. (eds) Protected Area Governance and Management. ANU Press, Canberra.

IUCN (2016). A Global Standard for the Identification of Key Biodiversity Areas. First edition. IUCN: Gland, Switzerland.

IUCN (2017). Green List of Protected and Conserved Areas Standard. https://www.iucn.org/theme/protected-areas/ourwork/iucn-green-list

IUCN/WCPA (2018). Special Issue on "Other Effective Areabased Conservation Measures". PARKS 24. IUCN: Gland. https://doi.org/10.2305/IUCN.CH.2018.PARKS-24-SI.en

Jonas, H., Barbuto, V., Jonas, H.C., Kothari, A. and Nelson, F. (2014). 'New steps of change: looking beyond protected areas to consider other effective area based conservation measures'. PARKS 20 (2): 111-128.

Jonas, H. and MacKinnon, K. (Eds) (2016). Co-Chairs' Report of the First Meeting of International Experts of the Task Force on Other Effective Area-based Conservation Measures. IUCNWCPA: Gland, Switzerland. https://www.iucn.org/theme/ protected-areas/wcpa/what-we-do/oecms

Jonas, H. and MacKinnon, K. (Eds) (2016). Advancing Guidance on Other Effective Area-based Conservation Measures: Report of the Second Meeting of the IUCN-WCPA Task Force on Other Effective Area-based Conservation Measures. IUCN : Gland, Switzerland https://www.iucn.org/ theme/protected-areas/wcpa/what-we-do/oecms 
Jonas, H. and MacKinnon, K. (Eds) (2017). Using Case Studies to Enhance Guidance on Other Effective Area-based Conservation Measures: Report of Third Meeting of the IUCNWCPA Task Force on Other Effective Area-based Conservation Measures. IUCN-WCPA: Gland, Switzerland. https://www. iucn.org/theme/protected-areas/wcpa/what-we-do/oecms

Jonas, H. and Sandwith, T. (Eds) (2019). Towards Recognising, Reporting and Supporting OECMs: Report of the Fourth Expert Meeting of the IUCN-WCPA Task Force on Other Effective Area-based Conservation Measures. IUCN: Gland, Switzerland https://www.iucn.org/theme/protectedareas/wcpa/what-we-do/oecms

Jonas, H., MacKinnon, K., Dudley, N., Hockings, M., Jessen, S., Laffoley, D., MacKinnon, D., Matallana-Tobón, C., Sandwith, T., Waithaka J. and Woodley, S. (2018). 'Other effective area-based conservation measures: From Aichi Target 11 to the post-2020 Biodiversity Framework'. PARKS 24. IUCN: Gland.

Jupiter, S., Cohen, P., Weeks, R., Tawake, A. and Govan, H. (2014). 'Locally-managed marine areas: Multiple objectives and diverse strategies'. Pacific Conservation Biology 20. 10.1071/PC140165.

Laffoley, D., Dudley, N., Jonas, H., MacKinnon, D., MacKinnon, K., Hockings, M. and Woodley, S. (2017). 'An introduction to "other effective area-based conservation measures" under Aichi Target 11 of the Convention on Biological Diversity: origin, interpretation and some emerging ocean issues'. Journal of Aquatic Conservation 27 (Supplement 1): 130-137.

Leverington, F., Lemos Costa, K., Courrau, J., Pavese, H., Nolte, C., Marr, M., Coad, L., Burgess, N., Bomhard, B. and Hockings, M. (2010). Management effectiveness evaluation in protected areas - a global study, Second edition. The University of Queensland Brisbane, Australia.

Lopoukhine, N. and Dias, B.F. (2012). 'Editorial: What does Target 11 really mean?' PARKS 18 (1): 5-8.

MacKinnon, D., C.J. Lemieux, K. Beazley, S. Woodley, R. Helie, J. Perron, J. Elliott, C. Haas, J. Langlois, H. Lazaruk, T. Beechey, and P. Gray (2015). 'Canada and Aichi Biodiversity Target 11: understanding "other effective areabased conservation measures" in the context of the broader target'. Biodiversity and Conservation 24 (14): 3559-3581. DOl 10.1007/s10531-015-1018-1.

Matallana-Tobón, C., Santamaría, M., Areiza Tapias, A., Solano C. and Galán S. (2018). 'Rethinking nature conservation in Colombia: a case study of other effective area-based conservation measures'. PARKS 24. IUCN: Gland. https://doi.org/10.2305/IUCN.CH.2018.PARKS-24-SICLM.en

Mathur, V. B., Onial, M. and Mauvais, G. (2015) "Managing threats", in G. L. Worboys, M. Lockwood, A. Kothari, S. Feary and I. Pulsford (eds). Protected Area Governance and Management, pp. 473-494, ANU Press, Canberra.

Mitchell, B., Fitzsimons, J., Stevens, C. and Wright, D. (2018). 'PPA or OECM? Differentiating between privately protected areas and other effective area-based conservation measures on private land'. PARKS 24. IUCN: Gland. https://doi. org/10.2305/IUCN.CH.2018.PARKS-24-SIBAM.en
Mwamidi, D.M., Renom, J.G. Fernández-Llamazares, Á., Burgas, D., Domínguez, P. and Cabeza, M. (2018). 'Contemporary pastoral commons in East Africa as OECMs: a case study from the Daasanach community'. PARKS 24. IUCN: Gland.

UNEP-WCMC and IUCN (2016). Protected Planet Report 2016. UNEP-WCMC and IUCN: Cambridge UK and Gland, Switzerland.

UNEP-WCMC, 2017. World Database on Protected Areas User Manual 1.5. UNEP-WCMC: Cambridge, UK. Available at: http://wcmc.io/WDPA_Manual

UNEP-WCMC and IUCN (2018). Protected Planet Report 2018. UNEP-WCMC and IUCN: Cambridge UK and Gland, Switzerland. https://portals.iucn.org/library/ node/48344

UNEP-WCMC (2018). 2018 United Nations List of Protected Areas. Supplement on protected area management effectiveness. UNEP-WCMC: Cambridge, UK.

United Nations (2007). United Nations Declaration on the Rights of Indigenous Peoples. Available at: https://www. un.org/development/desa/indigenouspeoples/wp-content/ uploads/sites/19/2018/11/UNDRIP_E_web.pdf

Utomo, A.B. and Walsh T.A. (2018). 'Hutan Harapan ecosystem restoration concession, Sumatra, Indonesia: a potential OECM?' PARKS 24. IUCN: Gland. https://doi. org/10.2305/IUCN.CH.2018.PARKS-24-SIABU.en

Waithaka, J. and Warigia Njoroge, G. (2018). 'The role of potential OECMs in safeguarding space for nature in Kenya: $A$ case study of wildlife conservancies'. PARKS 24. IUCN: Gland.

Watson, James EM, Nigel Dudley, Daniel B. Segan, and Marc Hockings. 'The performance and potential of protected areas'. Nature 515, no. 7525 (2014): 67.

Woodley, S., Bertzky B., Crawhall, N., Dudley, N., Miranda Londoño, J., MacKinnon, K., Redford, K.R. and Sandwith, T. (2012). 'Meeting Aichi Target 11: What does success look like for protected area systems?' PARKS 18 (1): 23-36.

Woodley, S., MacKinnon, K., McCanny, S., Pither, R., Prior, K. Salafsky, N. and Lindenmayer, D. (2015). 'Managing protected areas for biological diversity and ecosystem functions', in Worboys, G.L., Lockwood, M., Kothari, A., Feary, S. and Pulsford, I. (eds.) Protected Area Governance and Management, pp. 651-684, ANU Press, Canberra. http://press.anu.edu.au/ wpcontent/uploads/2015/02/CHAPTER21.pdf

Zarnetske, P.L., Read, Q.R., Record, S., Gaddis, K.D., Pau, S., Hobi, M.L., Malone, S.L., Costanza, J., Dahlin K.M., Latimer A.M., Wilson, A.M., Grady, J.M., Ollinger, S.V. and Finley A.O. (2019). 'Towards connecting biodiversity and geodiversity across scales with satellite remote sensing'. Ecological Soundings. https://doi.org/10.1111/geb.12887 


\section{Appendix I}

\section{The Broad relationship between the Aichi Targets and Target 11}

(Adapted from Laffoley et al., 2017)

\begin{tabular}{|c|c|c|}
\hline Target & Text & Relationship to Target 11 \\
\hline T3 & $\begin{array}{l}\text { By } 2020 \text {, at the latest, incentives, including } \\
\text { subsidies, harmful to biodiversity are } \\
\text { eliminated, phased out or reformed in order } \\
\text { to minimise or avoid negative impacts, and } \\
\text { positive incentives for the conservation } \\
\text { and sustainable use of biodiversity are } \\
\text { developed and applied, consistent and in } \\
\text { harmony with the Convention and other } \\
\text { relevant international obligations, taking into } \\
\text { account national socioeconomic conditions. }\end{array}$ & $\begin{array}{l}\text { Positive incentives for the conservation and sustainable use of } \\
\text { biodiversity that result in the area-based in-situ conservation } \\
\text { of nature, such as tax incentives for owners of privately } \\
\text { conserved areas, are examples of Target } 3 \text { measures that also } \\
\text { contribute to the achievement of Target } 11 \text {. }\end{array}$ \\
\hline T4 & $\begin{array}{l}\text { By } 2020 \text {, at the latest, Governments, } \\
\text { business and stakeholders at all levels have } \\
\text { taken steps to achieve or have implemented } \\
\text { plans for sustainable production and } \\
\text { consumption and have kept the impacts } \\
\text { of use of natural resources well within safe } \\
\text { ecological limits. }\end{array}$ & $\begin{array}{l}\text { Sustainable production plans (T4 measures) may include } \\
\text { unexploited reference, "insurance policy", or "seed source" } \\
\text { set-aside areas, which help to ensure that use of a broader } \\
\text { area is sustainable. If such set asides are effective for the } \\
\text { long-term in-situ conservation of biodiversity, they may } \\
\text { contribute to Target } 11 .\end{array}$ \\
\hline T5 & $\begin{array}{l}\text { By } 2020, \text { the rate of loss of all natural } \\
\text { habitats, including forests, is at least halved } \\
\text { and where feasible brought close to zero, } \\
\text { and degradation and fragmentation is } \\
\text { significantly reduced. }\end{array}$ & $\begin{array}{l}\text { The establishment of Target } 11 \text { areas is one important means } \\
\text { of achieving Target } 5 \text {. Establishing areas that are effective for } \\
\text { the long-term in-situ conservation of nature, whether protected } \\
\text { areas or OECMs, can prevent loss of natural habitats, and } \\
\text { degradation and fragmentation of ecosystems, especially if } \\
\text { such areas are well managed. In a terrestrial context this may } \\
\text { relate to primary forests and in a marine context this might be } \\
\text { particularly valid in the case of habitats such as coral reefs, } \\
\text { seagrass beds and submarine mounts. }\end{array}$ \\
\hline T6 & $\begin{array}{l}\text { By } 2020 \text { all fish and invertebrate stocks and } \\
\text { aquatic plants are managed and harvested } \\
\text { sustainably, legally and applying ecosystem- } \\
\text { based approaches, so that overfishing is } \\
\text { avoided, recovery plans and measures are } \\
\text { in place for all depleted species, fisheries } \\
\text { have no significant adverse impacts } \\
\text { on threatened species and vulnerable } \\
\text { ecosystems and the impacts of fisheries on } \\
\text { stocks, species and ecosystems are within } \\
\text { safe ecological limits. }\end{array}$ & $\begin{array}{l}\text { Target } 11 \text { areas can help ensure that exploitation of the } \\
\text { elements of biodiversity in the wider seascape is sustainable } \\
\text { by: providing benchmarks against which the effects of } \\
\text { management decisions can be evaluated; "insurance } \\
\text { policy" and "seed source" functions to enable recovery from } \\
\text { management failures; and/or provide "spillover" benefits in the } \\
\text { wider seascape. Species or habitat conservation measures } \\
\text { which apply broadly across wider seascapes rather than to } \\
\text { distinct and well-defined geographic areas which are not in } \\
\text { place for the long-term, should map to Target } 6 \text {. Sustainable } \\
\text { use of biological resources may be an objective for some } \\
\text { Target } 11 \text { areas. The key difference between Target } 11 \text { and } \\
\text { Target } 6 \text { area-based measures is that Target } 11 \text { areas achieve } \\
\text { the in-situ conservation of nature as a whole, and this outcome } \\
\text { cannot be compromised by allowed uses. }\end{array}$ \\
\hline T7 & $\begin{array}{l}\text { By } 2020 \text { areas under agriculture, } \\
\text { aquaculture and forestry are managed } \\
\text { sustainably, ensuring conservation of } \\
\text { biodiversity. }\end{array}$ & $\begin{array}{l}\text { Target } 11 \text { areas embedded within landscapes managed } \\
\text { primarily for agriculture, aquaculture, or forestry can } \\
\text { help ensure that such activities do not cause irreversible } \\
\text { biodiversity loss over wider landscapes by providing } \\
\text { benchmarks against which the effects of management } \\
\text { decisions can be evaluated. They can also provide "insurance } \\
\text { policy" and "seed source" functions to enable recovery from } \\
\text { management failures, "spillover" benefits, and contributions to } \\
\text { connectivity in the wider landscape. }\end{array}$ \\
\hline
\end{tabular}




\begin{tabular}{|c|c|c|}
\hline Target & Text & Relationship to Target 11 \\
\hline T9 & $\begin{array}{l}\text { By } 2020 \text {, invasive alien species and pathways } \\
\text { are identified and prioritised, priority species } \\
\text { are controlled or eradicated, and measures } \\
\text { are in place to manage pathways to prevent } \\
\text { their introduction and establishment. }\end{array}$ & $\begin{array}{l}\text { Target } 11 \text { areas with management objectives to maintain } \\
\text { or restore ecological integrity may be a focus for Target } 9 \\
\text { measures to eradicate alien species. }\end{array}$ \\
\hline T10 & $\begin{array}{l}\text { By } 2015 \text {, the multiple anthropogenic } \\
\text { pressures on coral reefs, and other } \\
\text { vulnerable ecosystems impacted by } \\
\text { climate change or ocean acidification are } \\
\text { minimized, so as to maintain their integrity } \\
\text { and functioning. }\end{array}$ & $\begin{array}{l}\text { Target } 11 \text { measures can have value in protecting coral } \\
\text { reefs and other vulnerable ecosystems from anthropogenic } \\
\text { pressures such as habitat degradation and species } \\
\text { overexploitation. However, Target } 11 \text { measures cannot, on } \\
\text { their own, fully address threats from climate change and } \\
\text { ocean acidification, which necessitate reductions in global } \\
\text { greenhouse gases. }\end{array}$ \\
\hline T12 & $\begin{array}{l}\text { By } 2020 \text { the extinction of known threatened } \\
\text { species has been prevented and their } \\
\text { conservation status, particularly of those } \\
\text { most in decline, has been improved and } \\
\text { sustained. }\end{array}$ & $\begin{array}{l}\text { Target } 11 \text { measures are a major tool for preventing extinction } \\
\text { and aiding recovery of threatened species, through the long- } \\
\text { term in-situ conservation of species and their associated } \\
\text { ecosystems. Target } 12 \text { measures focused on single species } \\
\text { and which are not area-based, not long-term, or not achieved } \\
\text { through in-situ conservation of biodiversity as a whole, are } \\
\text { not also Target } 11 \text { measures. Target } 11 \text { measures can prevent } \\
\text { extinction and aid recovery of threatened species, thus } \\
\text { contributing to Target } 12 \text {. }\end{array}$ \\
\hline T14 & $\begin{array}{l}\text { By } 2020, \text { ecosystems that provide essential } \\
\text { services, including services related to water, } \\
\text { and contribute to health, livelihoods and } \\
\text { well-being, are restored and safeguarded, } \\
\text { taking into account the needs of women, } \\
\text { indigenous and local communities, and the } \\
\text { poor and vulnerable. }\end{array}$ & $\begin{array}{l}\text { Target } 11 \text { measures can be a means of helping achieving } \\
\text { Target } 14 \text { by protecting ecosystems that provide a variety } \\
\text { of services. Some measures aimed at achieving Target } 14 \\
\text { may also be recognised as contributions to Target } 11 \text { if they } \\
\text { are achieved through the long-term in-situ conservation of } \\
\text { biodiversity, regardless of their primary objectives. In a marine } \\
\text { context this might be maintenance of coral reefs or mangroves } \\
\text { as part of coastal protection against storms and ocean surge, } \\
\text { for example. And what might be a terrestrial example? }\end{array}$ \\
\hline T15 & $\begin{array}{l}\text { By } 2020 \text {, ecosystem resilience and the } \\
\text { contribution of biodiversity to carbon stocks } \\
\text { has been enhanced, through conservation } \\
\text { and restoration, including restoration of at } \\
\text { least } 15 \text { per cent of degraded ecosystems, } \\
\text { thereby contributing to climate change } \\
\text { mitigation and adaptation and to combating } \\
\text { desertification. }\end{array}$ & $\begin{array}{l}\text { Target } 11 \text { areas, because of their generally higher levels of } \\
\text { ecological integrity than exploited landscapes and seascapes, } \\
\text { are often more resilient, more diverse, and store more carbon. } \\
\text { Protecting intact areas, and protecting and restoring degraded } \\
\text { areas, are two ways Target } 11 \text { measures can contribute to } \\
\text { through the long-term in situ conservation of biodiversity may } \\
\text { be recognised as Target } 11 \text { areas. }\end{array}$ \\
\hline T18 & $\begin{array}{l}\text { By 2020, the traditional knowledge, } \\
\text { innovations and practices of indigenous } \\
\text { and local communities relevant for the } \\
\text { conservation and sustainable use of } \\
\text { biodiversity, and their customary use } \\
\text { of biological resources, are respected, } \\
\text { subject to national legislation and relevant } \\
\text { international obligations, and fully integrated } \\
\text { and reflected in the implementation of } \\
\text { the Convention with the full and effective } \\
\text { participation of indigenous and local } \\
\text { communities, at all relevant levels. }\end{array}$ & $\begin{array}{l}\text { Target } 11 \text { measures can contribute to Target } 18 \text { by helping } \\
\text { ensure that the areas in which traditional knowledge, } \\
\text { innovations, and practices of indigenous and local } \\
\text { communities have developed, and where their customary uses } \\
\text { of biological resources occur, remain ecologically intact and } \\
\text { able to sustain such activities for the long term. Conversely } \\
\text { some traditionally managed indigenous areas may contribute } \\
\text { to Target } 11 \text {, for example some sacred natural sites that are } \\
\text { not part of the formal protected area network. }\end{array}$ \\
\hline
\end{tabular}




\section{Appendix II}

\section{Decision support: Is Aichi Target 11 the most appropriate Aichi Target against which to evaluate a conservation measure?}

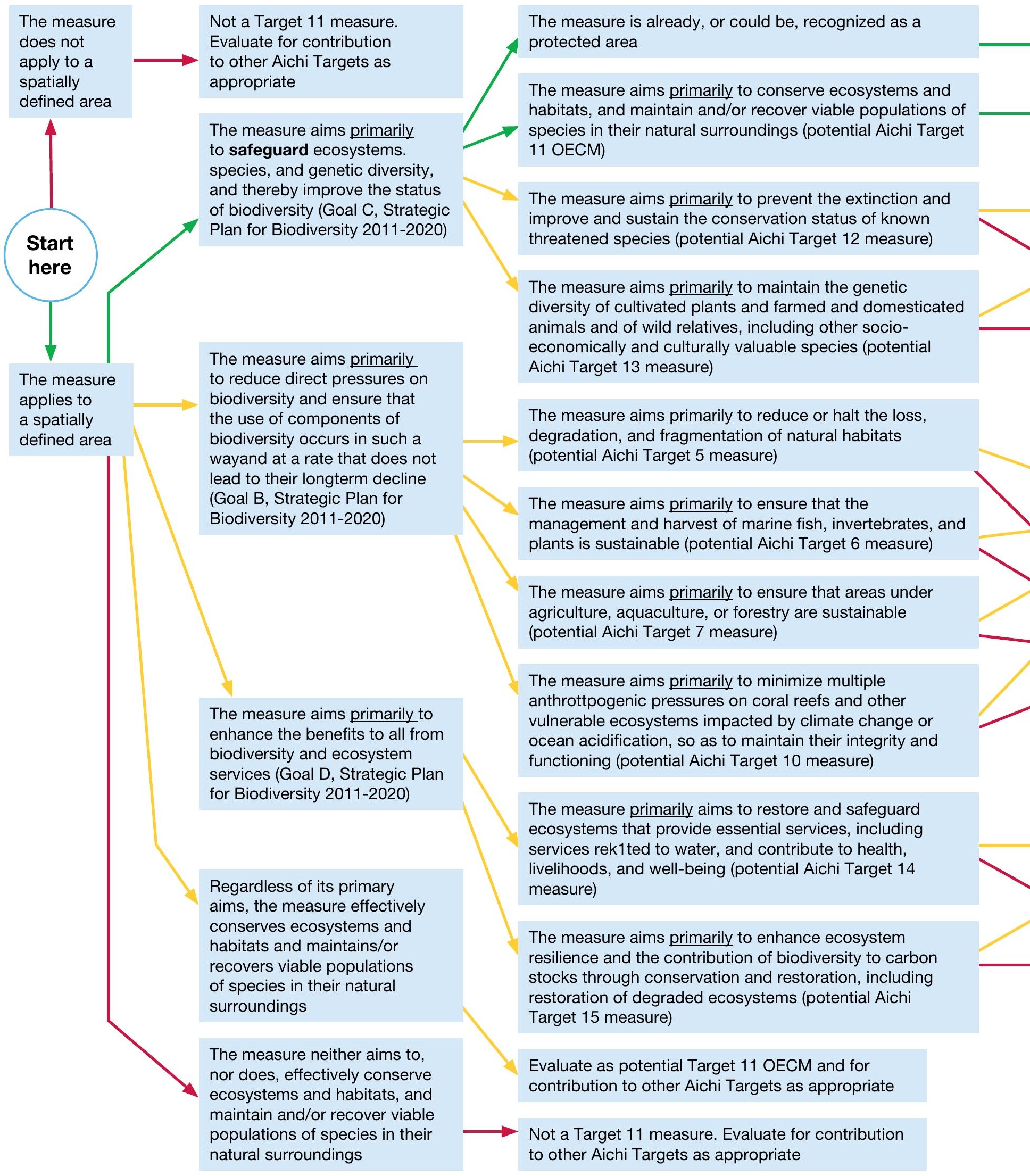


Report as protected area under Target 11 and evaluate contribution to other Targets as appropriate

The measure achieves its aims by conserving ecosystems and habitats, and maintaining and/ or recovering viable populations of species in their natural surroundings

The measure does not achieve its aims by conserving ecosystems and habitats, and maintaining and/or recovering viable populations of species in their natural surroundings
Evaluate as potential Target 11 OECM and for contribution to other Targets as appropriate

Evaluate as potential Target 11 OECM and for contribution under Targets 12, 13 or others as appropriate

Not a Target 11 measure. Evaluate for contribution under Target 12, 13, or others as appropriate
The measure achieves its aims by comprehensively conserving ecosystems and habitats, and maintaining and/or recovering viable populations of species in their natural surroundings

The measure does not achieve its aims by comprehensively conserving ecosystems and habitats, and maintaining and/or recovering viable populations of species in their natural surroundings
Evaluate as potential Target $11 \mathrm{OECM}$ and for contribution under Targets 5, 6, 7, 10 or others as appropriate

Not a Target 11 measure. Evaluate for contribution under Targets 5, 6, 7, 10 or others as appropriate
The measure achieves its aims by conserving ecosystems and habitats, and maintaining and/ or recovering viable populations of species in their natural surroundings

The measure does not achieve its aims by conserving ecosystems and habitats, and maintaining and/or recovering viable populations of species in their natural surroundings

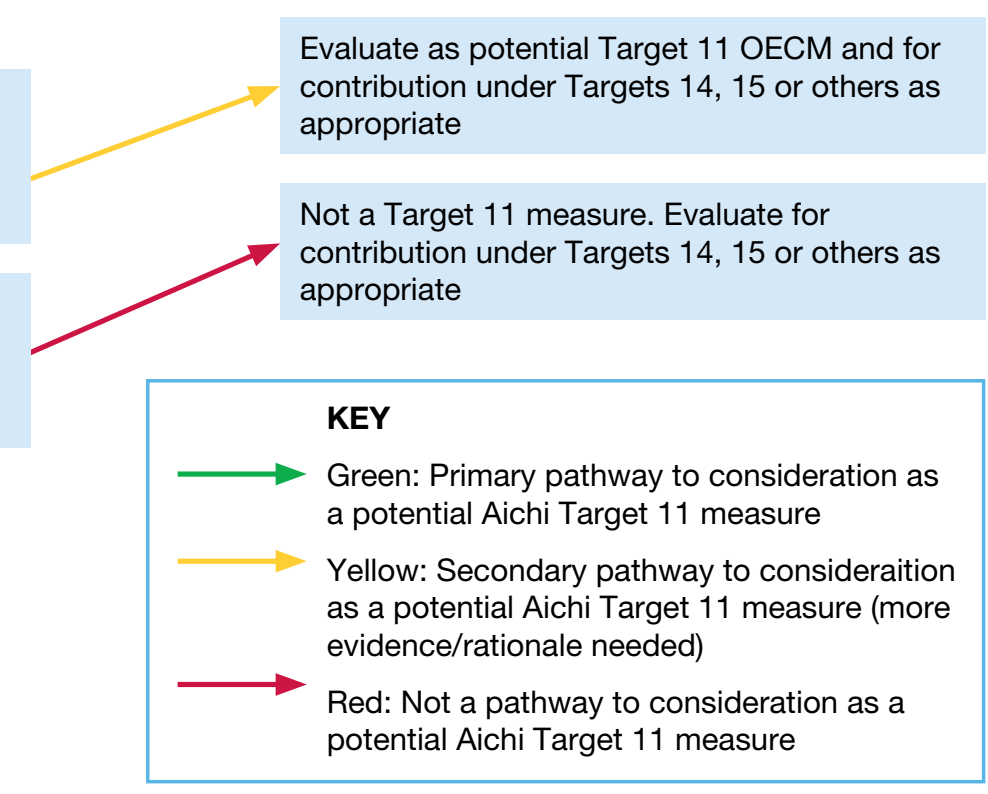




\section{Appendix III}

\section{Protected Planet Databases on Protected Areas and OECMs}

All data on other effective area-based conservation measures (OECMs/conserved areas) should be submitted to the UN Environment World Conservation Monitoring Centre (UNEPWCMC) to be added to the World Database on Protected Areas (WDPA).

Additional guidance will be available here: www.wcmc.io/conservedareas_guidance

\section{What is the World Database on Protected Areas?}

The WDPA is the most comprehensive global database of marine and terrestrial protected areas, comprising both spatial data (i.e., boundaries and points) with associated attribute data (i.e., tabular information), collected in a standardised way. Source information is also maintained for all datasets submitted. The WDPA is updated on a monthly basis and made available and downloadable online through Protected Planet with the exception of data that have sharing restrictions placed on them by data providers. The WDPA User Manual (UNEP-WCMC, 2017) provides detailed information and guidance about the data held within the WDPA, including its collation and data standards.

The new OECM database follows the same structure as the WDPA, with minor modifications. The WDPA and OECM databases are the official data sources used for several global reporting mechanisms, informing indicators and tracking progress towards protected and conserved area targets, including for the CBD Strategic Plan Aichi Biodiversity Targets and the UN Sustainable Development Goals (SDGs).

\section{Reporting, data collection and validation of Protected Areas and OECMs}

Usually data is submitted to the WDPA or OECM database by the governance authority for the protected or conserved area, and this data has priority over data submissions on the same area from other sources. When the governance authority is not able to provide an update due to lack of capacity, lack of data or other circumstance, they may suggest another provider to be contacted for an update. All sites should meet the IUCN/ CBD definition of a protected area or "other effective areabased conservation measure".
Only one version of any protected or conserved area is stored in the Protected Planet databases. Where there are overlapping areas, these are typically different designations that cover the same geographical space.

All data in the WDPA or OECM database must meet a set of data standards. Standards are important to ensure all information is supplied in a common format that is interoperable and useful for a wide variety of reporting and analytical purposes. There are four key requirements that need to be met to comply with the Protected Planet data standards:

1. All sites should meet the IUCN/CBD definition of a protected area or "other effective area-based conservation measure".

2. Spatial data from Geographic Information Systems (GIS) and an associated list of standardised attributes must be provided.

3. Source of information must be provided to ensure that ownership of the data is maintained and traceable.

4. A Data Contributor Agreement must be signed to ensure that there is a written record of the data provider agreeing that the data be included in the WDPA or OECM database and the terms under which it is made available.

Using the Protected Planet databases to measure progress against Targets

UNEP-WCMC uses data in the Protected Planet databases to measure progress against international conservation goals, such as Aichi Biodiversity Target 11. For reporting on Target 11, three statistics will be generated, for national, regional and global level:

- Protected area coverage;

- Other effective area-based conservation measures coverage; and

- Combined coverage.

To calculate coverage, UNEP-WCMC removes overlaps between sites, and excludes certain categories of sites (those that are proposed, points with no reported area, and UNESCO Man and Biosphere Reserves). Although conserved areas and protected areas would not normally occupy the same area (see Section 3.2 b), there may be occasional cases of overlap. In such cases, the area of overlap is treated as a protected area only. This method avoids double-counting. Further information on how UNEP-WCMC calculates coverage statistics is available at https://protectedplanet.net/c/ calculating-protected-area-coverage 


\title{
Monitoring other effective area- based conservation measures
}

\author{
Protected Areas Management Effectiveness (PAME) will in \\ many cases be the most pragmatic way to measure the \\ effectiveness of conserved areas, especially where the PAME \\ tools are supported by additional information on biodiversity \\ outcomes. Over 40 tools have been developed for PAME \\ assessments (see UNEP-WCMC 2018). The adoption of \\ existing PAME systems means that it will be easier for the \\ authority to report on effectiveness monitoring to UNEP- \\ WCMC, and that assessments will be in a standardised format \\ between sites and over time.
}

Some basic principles for monitoring conserved areas to track effective conservation are described in steps 1-4 below. Steps 1-3 can also be used to support the decision as to whether a site is a conserved area, or is still effectively conserved on repeat assessments.

5. Describe all significant biodiversity values on the site, with a record of the sources of information to support this. Consider representativeness, intactness, landscape context, rare, threatened, endemic and significant species and habitats and ecological integrity.

6. Identify pressures and threats to the site that will impact the biodiversity values.

7. Review the management inputs and measures undertaken on the site to assess their effectiveness, whether they are sufficient to maintain the biodiversity features, and if they cover the full scope of biodiversity on the site, and address controllable threats to in-situ conservation of biodiversity.

8. Review the effectiveness in terms of the conservation outcomes on the site, through measuring the status of priority attributes, setting and reviewing targets and indicators that measure status and trends over time, measuring mitigation of threats, monitoring and managing adaptively.

Reporting to the Global Database on Protected Areas Management Effectiveness (GD-PAME) managed by UNEPWCMC follows a similar approach to that outlined above for the WDPA and OECM database. For any queries regarding reporting, collation, use, or processing of the GD-PAME, please contact: protectedareas@unep-wcmc.org. 
22 Recognising and reporting other effective area-based conservation measures 



\section{IUCN}

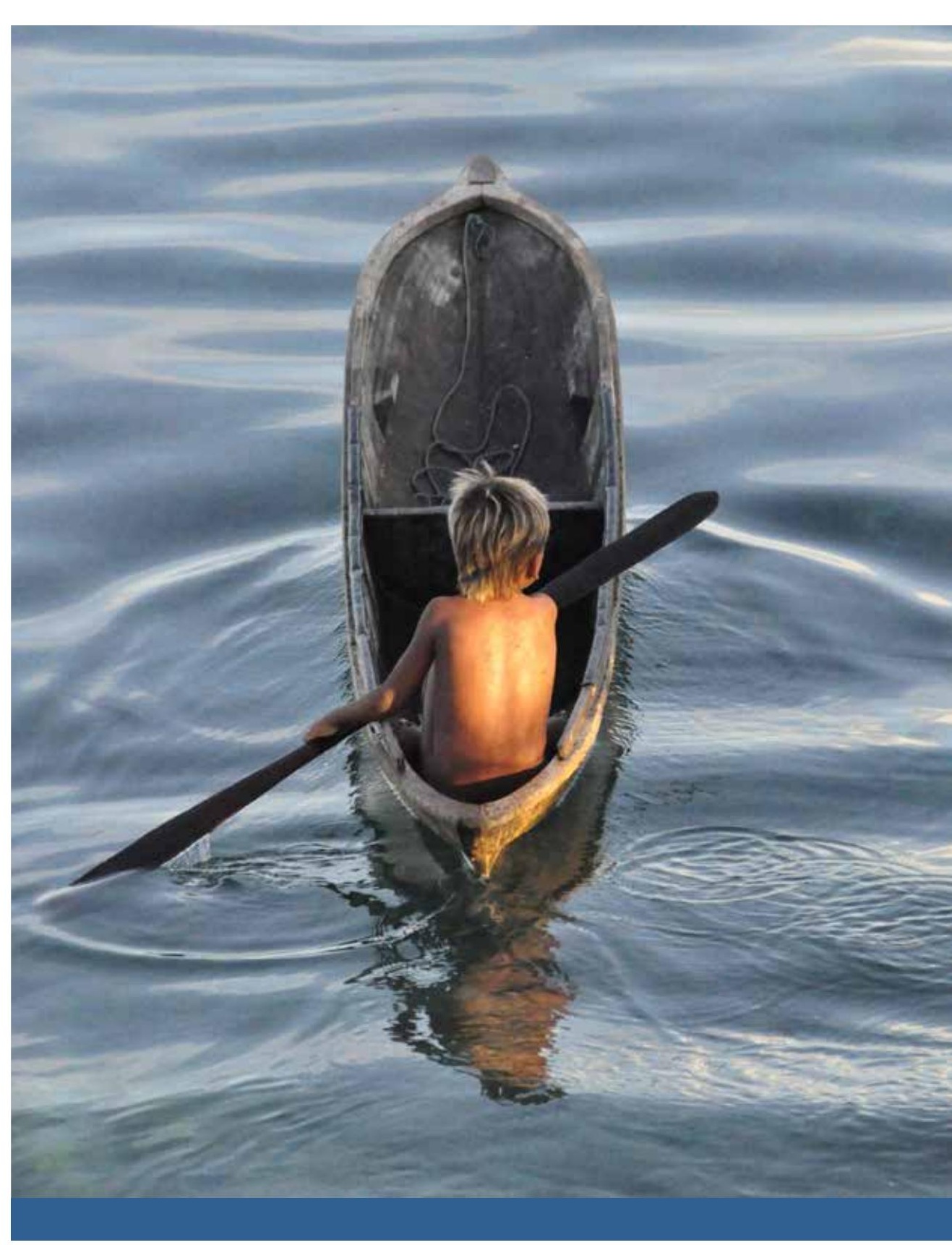

INTERNATIONAL UNION FOR CONSERVATION OF NATURE

WORLD HEADQUARTERS

Rue Mauverney 28

1196, Gland, Switzerland

Tel: +41 229990000

Fax: +41229990002

www.iucn.org 